\title{
Helminth Antigen-Conditioned Dendritic Cells Generate Anti-Inflammatory Cd4 T Cells Independent of Antigen Presentation via Major Histocompatibility Complex Class II
}

Chelsea E. Matisz, ${ }^{*}$ Markus B. Geuking, ${ }^{\dagger}$ Fernando Lopes, ${ }^{*}$ Björn Petri, ${ }^{\ddagger}$ Arthur Wang, ${ }^{*}$ Keith A. Sharkey, ${ }^{* \S}$ and Derek M. McKay*

From the Gastrointestinal Research Group and Inflammation Research Network, * Department of Physiology and Pharmacology, the Department of Microbiology, Immunology and Infectious Diseases, ${ }^{\dagger}$ the Mouse Phenomics Resource Laboratory, ${ }^{\ddagger}$ Department of Microbiology, Immunology and Infectious Diseases, Snyder Institute for Chronic Diseases, and the Hotchkiss Brain Institute, ${ }^{\S}$ Cumming School of Medicine, University of Calgary, Calgary, Alberta, Canada

\author{
Accepted for publication \\ July 16, 2018. \\ Address correspondence to \\ Derek M. McKay, Ph.D., \\ Department of Physiology and \\ Pharmacology, University of \\ Calgary, 3330 Hospital Dr. \\ N.W., Calgary, AB T2N 4N1, \\ Canada. E-mail: dmckay@ \\ ucalgary.ca.
}

\begin{abstract}
A recently identified feature of the host response to infection with helminth parasites is suppression of concomitant disease. Dendritic cells (DCs) exposed to antigens from the tapeworm Hymenolepis diminuta significantly reduce the severity of dinitrobenzene sulfonic acid-induced colitis in mice. Here we elucidate mechanisms underlying this cellular immunotherapy. We show a requirement for Ccr7 expression on transferred $H$. diminuta antigen-treated (HD)-DCs, suggesting that homing to secondary lymphoid tissues is important for suppression of colitis. Furthermore, sodium metaperiodate-sensitive helminth-derived glycans are required to drive the anti-colitic response in recipient mice. Induction of Th2-type cytokines and Gata- $3^{+} \mathrm{Cd}^{+}$cells in secondary lymphoid tissues is dependent on major histocompatibility complex class II (MHC II) protein expression on transferred DCs, although remarkably, transfer of $\mathrm{MHC} \mathrm{II}^{-/-} \mathrm{HD}$-DCs still attenuated dinitrobenzene sulfonic acid-induced colitis in recipient mice. Moreover, transfer of $\mathrm{Cd}^{+}$splenic $\mathrm{T}$ cells retrieved from mice administered $\mathrm{MHC} \mathrm{II}^{-/-} \mathrm{HD}-\mathrm{DCs}$ suppressed dinitrobenzene sulfonic acid-induced colitis in recipient mice. Our studies reveal that HD-DCs can suppress colitis via an alternative MHC II-independent pathway that involves, in part, mobilization of T-cell responses. These data support the utility of HD-DCs in blocking colitis, revealing a requirement for Ccr7 and providing for HD-DC autologous immunotherapy for disease in which MHC II expression and/or function is compromised. (Am J Pathol 2018, 188: 2589-2604; https://doi.org/ 10.1016/j.ajpath.2018.07.008)
\end{abstract}

Adoptive transfer of autologous dendritic cells (DCs) can enhance immunogenicity toward tumor antigens in patients with a wide variety of cancers. ${ }^{1}$ Furthermore, DC vaccination has been evaluated in the context of infectious diseases; clinical trials have shown that autologous DCs loaded with heatinactivated HIV can reduce viral load in patients with HIV.,3 Preclinical studies support DC immunotherapy in inflammatory bowel disease via the development of a tolerogenic DC phenotype. ${ }^{4}$ Also, DCs pulsed with bacterial proteins, extracts of Enterobacteria spp., or the neuropeptide vasoactive intestinal peptide, or engineered to express FasL all have regulatory/ tolerogenic properties that protect mice from colitis. ${ }^{5}$
Supported by Natural Sciences and Research Council of Canada grant RGPIN-2017-03826 (D.M.M.), Canadian Institutes of Health Research grants PJT 391060 (M.B.G.) and FDN 148380 (K.A.S.), and a grant from Alberta Innovates (C.E.M. and F.L.). The Flow Cytometry suite and the Snyder Mouse Phenomics Resources Laboratory were supported by the University of Calgary.

M.B.G. and F.L. contributed equally to this work.

Disclosures: D.M.M. holds a Canada Research Chair (Tier 1) in Intestinal Immunophysiology in Health and Disease. K.A.S. holds a Crohn's and Colitis Canada Chair in IBD Research at the University of Calgary.

Current address of C.E.M., The Canadian Center for Behavioral Neuroscience, Department of Neuroscience, University of Lethbridge. 
Substantial data from animal models and a few small clinical trials indicate that infection with helminth parasites can ameliorate autoinflammatory diseases, including inflammatory bowel disease. ${ }^{8}$ Although promising, helminth therapy in a larger trial in Crohn disease ${ }^{9}$ and multiple sclerosis ${ }^{10}$ provided no major benefit to the patient. Even though it is well tolerated, helminth therapy is not without caveats: There are reports of unwanted side effects (eg, transient diarrhea, anemia, gastrointestinal pain), iatrogenic disease is a concern, ${ }^{11,12}$ and the putative psychological discomfort associated with harboring a live parasite should not be discounted. Such concerns are mitigated when helminth-derived molecules, ${ }^{13,14}$ or adoptive transfer of helminth antigen-treated cells, are used to treat disease. ${ }^{8,15-17}$ Murine bone marrow-derived DCs exposed to a crude extract of the tapeworm Hymenolepis diminuta (HD-DCs) reduce the severity of dinitrobenzene sulfonic acid (DNBS)-induced colitis in mice via the mobilization of adaptive immunity-specifically, splenic $\mathrm{Cd}^{+} \mathrm{T}$ cells-and via Il-4 and Il-10. ${ }^{18,19}$ These findings raise a number of mechanistic issues that are important to address if helminth-based cellular immunotherapy is to become a therapeutic option: What is the molecular basis of the HD extract that drives a DC to evoke anti-colitic events, and how is this mediated?

Utilizing this model, in an effort to understand the mechanistic basis of HD-DC suppression of colitis as proof of concept to apply this approach to human disease, we show that a sodium metaperiodate-sensitive glycan(s) in the HD extract is required for the anti-colitic effect of HDDCs. A requirement for Ccr-7 expression on the DC is observed and, by implication, homing to secondary lymphoid organs (SLOs) is important in the suppression of chemical-induced colitis. Moreover, and uniquely in the realm of helminth therapy, we have discovered a novel antiinflammatory pathway, operating via $\mathrm{Cd}^{+} \mathrm{T}$ cells in a major histocompatibility complex class II (MHC II)independent manner that was not accompanied by increased production of Il-10 or Il-4 by splenocytes from the HD-DC-recipient mice. The latter data not only indicate the putative utility of HD-DCs to block colitis, they also suggest that autologous immunotherapy for HD-DC may be of value in the treatment of disease in which MHC II expression/ function is compromised, as is the case in some viral infections, including herpes and HIV. ${ }^{20,21}$

\section{Materials and Methods}

Mice

Animal experiments followed protocols approved by the University of Calgary's Health Science Animal Care Committee (protocol AC13-0015), which conformed to the Canadian Council on Animal Care's guideline on animal research. Male BALB/C (Charles River Laboratories, St. Constant, Canada), MHC II knockout (KO) and wild- type (WT) controls (C57BL/6 background; The Jackson Laboratory, Bar Harbor, ME), Ccr7 KO and their WT littermate controls [C57BL/6 background; gift from Dr. Paul Kubes (University of Calgary, Calgary, AB, Canada); as previously published ${ }^{22}$ ], and C57BL6 recombinationactivating gene $1 \mathrm{KO}$ mice (colony at University of Calgary) were maintained at the Animal Research Center, University of Calgary, with free access to chow and water. Mice were used between 8 and 12 weeks of age, with only WT mice exposed to the colitis protocol.

\section{HD Extract}

Adult HD were flushed from the small intestine of rats, washed thoroughly, homogenized in phosphate-buffered saline (PBS), and centrifuged $(3220 \times g, 30$ minutes, $\left.4^{\circ} \mathrm{C}\right)$. The PBS-soluble component was recentrifuged, protein content was measured via Bradford assay, and aliquots were frozen at $-80^{\circ} \mathrm{C}$. Bioactivity of the extract was standardized by assessment of its capacity to suppress lipopolysaccharide-induced tumor necrosis factor $\alpha$ production ( 48 hours, $1 \mu \mathrm{g} / \mathrm{mL}$ ) by THP-1 macrophages by at least $40 \% .^{23}$ Trace levels of endotoxin were present in the antigen preparation $(65 \mathrm{pg} / \mathrm{mg}$ extract; ToxinSensor Chromogenic LAL kit; GenScript, Piscataway, NJ). ${ }^{18}$ For the assessment of the role of proteins, $100 \mu \mathrm{g} / \mathrm{mL}$ worm extract was treated with $1 \mathrm{mg}$ of proteinase $\mathrm{K}$ (InvitroGen Canada Inc., Burlington, ON, Canada) for 3 hours at $37^{\circ} \mathrm{C}$, then boiled for 20 minutes. To assess the role of glycans, $100 \mu \mathrm{g} / \mathrm{mL}$ worm extract was treated with $5 \mathrm{mg} / \mathrm{mL}$ sodium metaperiodate (Alfa Aesar, Tewksbury, MA) for 24 hours at room temperature, and subsequently dialyzed using $10 \mathrm{~K}$ MWCO Slide-A-Lyzer G2 dialysis cassettes (Thermo Scientific, Rockford, IL) following the manufacturer's instructions; dialyzed-only extract was used as a sham-treated control.

\section{Bone Marrow-Derived Dendritic Cells and Adoptive Transfer}

DCs were generated from bone marrow stem cells as described. ${ }^{18,24}$ Briefly, bone marrow stem cells were harvested from the femurs of mice and seeded at $5 \times 10^{6}$ cells/ $10 \mathrm{~mL}$ of RPMI medium (Sigma-Aldrich, St. Louis, MO) supplemented with $10 \%$ fetal bovine serum, $2 \%$ Pen/Strep, $1 \%$ GlutaMAX, and $1 \%$ sodium pyruvate (all, Gibco, Grand Island, NY) and $20 \mathrm{ng} / \mathrm{mL}$ recombinant murine granulocyte macrophage colony-stimulating factor (PeproTech, Montreal, Canada). On days 3 and 6, cells were given an additional 10 and $5 \mathrm{~mL}$ of supplemented medium containing 20 and $40 \mathrm{ng} / \mathrm{mL}$ granulocyte macrophage colonystimulating factor, respectively. On day 8, floating cells were collected, washed, and resuspended in $10 \%$ dimethyl sulfoxide in fetal bovine serum $\left(5\right.$ to $10 \times 10^{6}$ cells $\left./ \mathrm{mL}\right)$ for storage in liquid nitrogen. For adoptive transfer experiments, DCs were thawed, resuspended in supplemented 
RPMI medium, and rested overnight before treatment with worm extract $(100 \mu \mathrm{g} / \mathrm{mL})$ for 24 hours. On day 10, cells were $>90 \% \mathrm{Cd} 11 \mathrm{c}^{+}$, as determined by flow cytometry. DCs were washed three times in PBS, and resuspended in $500 \mu \mathrm{L}$ PBS ( 2 to $4 \times 10^{6}$ cells $/ \mathrm{mL}$ ). For localization experiments, a single i.p. injection of $2 \times 10^{6}$ cells was administered; for all other adoptive transfer experiments, a single dose of $1 \times 10^{6}$ cells was transferred i.p.

\section{Isolation of $\mathrm{Cd}^{+}{ }^{\mathrm{T}}$ Cells}

WT and MHC II ${ }^{-/-}$HD-DCs were transferred to mice, and 5 days later splenocytes were isolated and enriched for $\mathrm{Cd} 4^{+} \mathrm{T}$ cells, following protocols provided with the EasySep Mouse $\mathrm{Cd}^{+}{ }^{+}$T-cell enrichment kit (Stemcell Technologies, Vancouver, BC, Canada). For adoptive transfer experiments, $1 \times 10^{6} \mathrm{Cd}^{+} \mathrm{T}$ cells were resuspended in $500 \mu \mathrm{L}$ of sterile PBS and administered by i.p. injection.

\section{Induction and Assessment of Colitis}

Colitis was induced in anesthetized (4\% inhaled isoflurane) mice through intrarectal (i.r.) instillation of $3 \mathrm{mg}$ (BALB/C mice) or $4 \mathrm{mg}$ (C57BL/6 mice) of DNBS (MP Biomedicals, Santa Barbara, CA) dissolved in 100 $\mu \mathrm{L}$ of $50 \%$ ethanol using a polyethylene catheter inserted $3 \mathrm{~cm}$ from the anus ${ }^{25}$; negative control mice received $100 \mu \mathrm{L}$ of PBS. In mice that received adoptive cellular therapy, DNBS was administered 48 hours after cell transfer, with the exception of the recovery study, in which DCs were given directly after the DNBS.

Mice were examined daily for signs of disease and weight loss. At 72 hours after DNBS, colons were removed for macroscopic assessment, and a disease score was calculated based on previously published criteria ${ }^{18}$ : visceral adhesions, where 0 indicates absent, 1 indicates moderate, and 2 indicates severe; colonic shortening, calculated as the percentage relative to negative controls multiplied by 0.1 ; colonic inflammation, calculated as percentage relative to total length of the colon, multiplied by 0.05 ; diarrhea, fecal blood, and erythema, where 0 indicates absent and 1 indicates present; and ulceration, where 1 point was calculated per $1 \mathrm{~cm}$ of ulceration. A $1-\mathrm{cm}$ portion $20 \%$ from the distal end was removed, fixed in formalin, sectioned $(5 \mu \mathrm{m})$, and stained with hematoxylin and eosin. Histopathology score was calculated in a blinded fashion (C.E.M, A.W., and D.M.M.) using a 12-point scale ${ }^{25}$ : cellular infiltration, where 0 indicates absent and 1 to 3 indicates increasing severity; loss of architecture, where 0 indicates absent and 1 to 3 indicates increasing severity; muscle thickening, where 0 indicates absent and 1 to 2 indicates increasing severity; and goblet cell depletion, crypt abscess, edema, and ulcers, where 0 indicates absent and 1 indicates present. In other studies, when DCs were administered directly after DNBS, necropsy was performed 5 or 7 days later, as a treatment/ recovery protocol.

\section{Splenocyte Cytokine Synthesis}

Spleens were aseptically removed, and forced through a $100-\mu \mathrm{m}$ nylon mesh strainer using the plunger from a $10-\mathrm{mL}$ syringe. Erythrocytes were lysed with ammonium potassium chloride buffer for 90 seconds. Cytokine levels were assessed in the supernatants of splenocytes $\left(5 \times 10^{6}\right)$ stimulated with concanavalin A $(2 \mu \mathrm{g} / \mathrm{mL})$ for 48 hours; enzyme-linked immunosorbent assays for interferon- $\gamma$, Il-4, Il-10, Il-12p40, Il-17, transforming growth factor (Tgf)- $\beta$, and tumor necrosis factor $\alpha$ were performed using Duoset kits (R\&D Systems, Minneapolis, MN), as per the manufacturer's instructions. Cytokine levels in colonic homogenates were also examined.

\section{In Vivo Imaging}

In vivo imaging protocols followed those previously described. ${ }^{26}$ To reduce background fluorescence, mice were fed a modified AIM-93M diet (catalog number TD.00102; Harlan Laboratories, Frederick, MD) 7 days before experimentation. Mice were shaved 24 hours before imaging. Cells (8 to $10 \times 10^{6}$ DCs or splenocytes) were stained with VivoTrack 680 NIR (PerkinElmer, Waltham, MA) following the manufacturer's instructions, before adoptive cell transfer $\left(2 \times 10^{6}\right.$ i.p. $)$. Noninvasive whole-body imaging was performed using the In-Vivo Xtreme 4MP imaging platform (Bruker, Billerica, MA). Cells were visualized using $670-\mathrm{nm}$ excitation and $750-\mathrm{nm}$ emission wavelengths. Animals were imaged every 24 hours after cell transfer; mice were anesthetized ( $2 \%$ isoflurane) and kept at $37^{\circ} \mathrm{C}$ during the imaging protocol, which included reflectance imaging (2-second exposure), fluorescence imaging at 670/750 $\mathrm{nm}$ (6-second exposure), and X-ray imaging (10-second exposure). At 5 days after cell transfer, mice underwent necropsy: the heart, lung, liver, spleen kidneys, small intestine, colon, and mesenteric lymph nodes (MLNs) were removed for additional reflectance and fluorescence imaging. All images were acquired and analyzed using MI SE molecular imaging software version 7.1.3.20550 (Bruker).

\section{Flow Cytometry}

For cell localization experiments, splenocytes were stained for Cd11c [clone N418 (APC); BioLegend, San Diego, CA] after blocking with Cd16/32 (TruStain; BioLegend), and analyzed for Cd11c and VivoTrack 680 expression on an Acoustic Attune Flow Cytometer, using Attune software version 1.2 (Life Technologies, Carlsbad, CA). For analysis of T-cell phenotypes, the following fluorophoreconjugated antibody clones were used: Cd4 BV786 (catalog number GK1.5; BD Biosciences, San Jose, CA), Cd8 $\alpha$ AF700 (catalog number 53-6.7; BD Biosciences), trans-acting T-cell-specific transcription factor Gata-3 (Gata-3) PerCP/Cy5.5 (catalog number 16E10A23; BioLegend), T-box protein expressed in $\mathrm{T}$ cells (T-bet) 
BV421 (catalog number 04-46; BD Biosciences), ROR $\gamma \mathrm{t}$ PE (catalog number Q31-378; BD Biosciences), forkhead box protein P3 (Foxp3) fluorescein isothiocyanate (catalog number FJK-16s; eBioscience, San Diego, CA), and Helios Alexa Fluor 647 (catalog number 22F6; BD Biosciences). Cells were stained with a viability dye (catalog number FVS 780; BD Biosciences) before Fc blocking with $\mathrm{Cd} 16 / 32$ (TruStain; BioLegend) for 15 minutes, and stained for surface antibodies for 30 minutes. Cells were fixed and permeabilized following the manufacturer's instructions using the Foxp3 Fix/Perm kit (eBioscience), blocked with $5 \%$ rat serum for 15 minutes, and stained with intracellular antibodies overnight at $4{ }^{\circ} \mathrm{C}$. Data were collected using the Canto II system (BD Biosciences) and analyzed by FlowJo software version 9 (Tree Star,
Ashland, OR). All lymphocytes were gated on viability, and doublets were excluded before assessment of T-cell phenotypes.

\section{Statistical Analysis}

Data are presented as arithmetic means \pm SEM, and an $\alpha$ level of 0.05 was accepted as statistically significant. For parametric data, statistical outliers were removed using the Grubb test. For comparisons between two groups, a twotailed unpaired $t$-test was performed. For multiple groups, a one-way analysis of variance was used; for post hoc analysis among all groups, the Tukey test was used; to compare two specific groups, the Sidak test was performed. Significant differences in nonparametric data were assessed using the
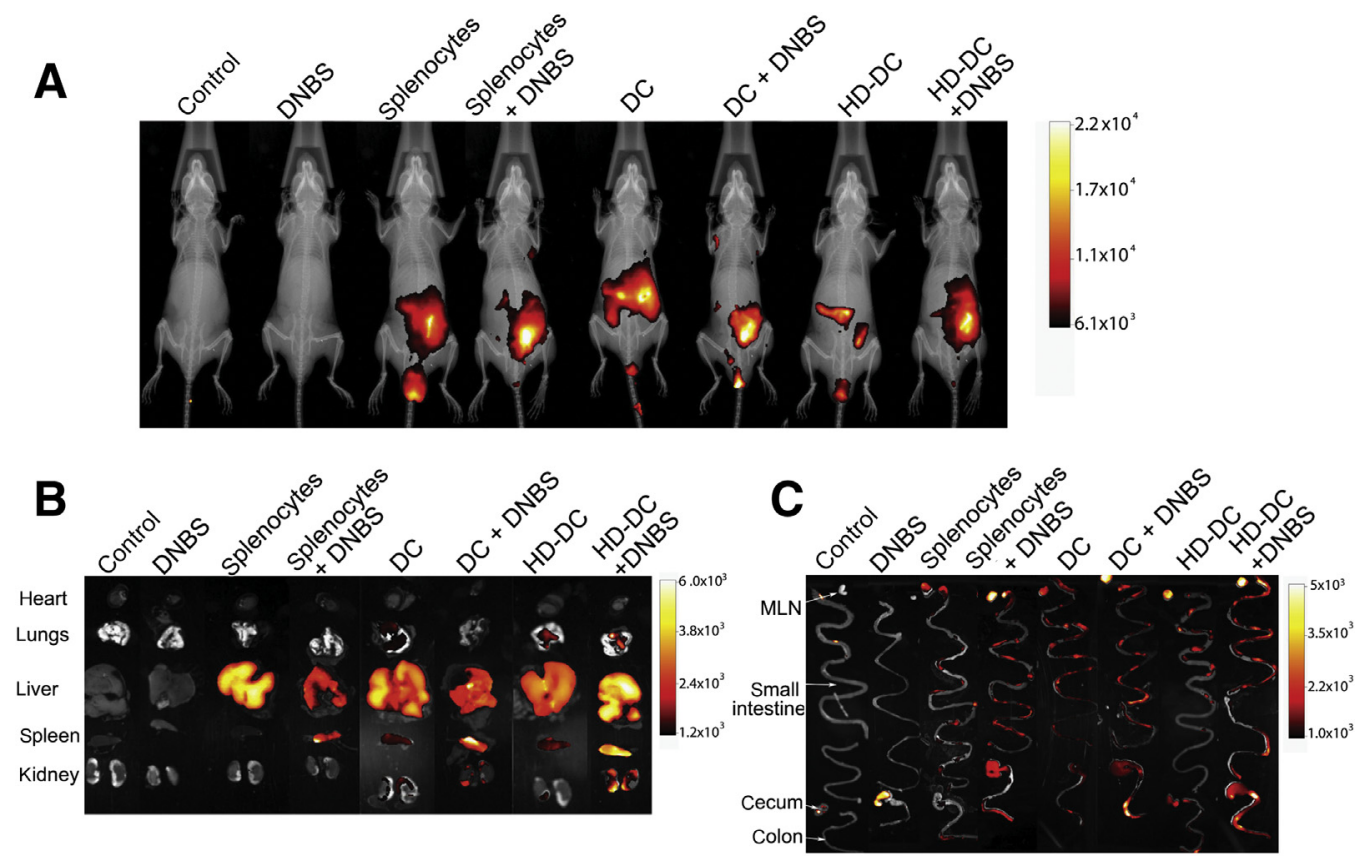

D

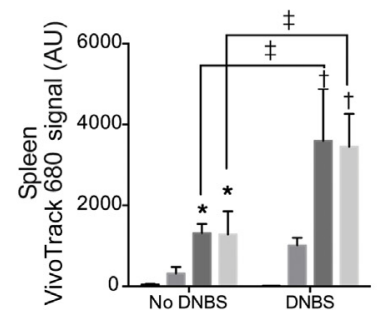

E

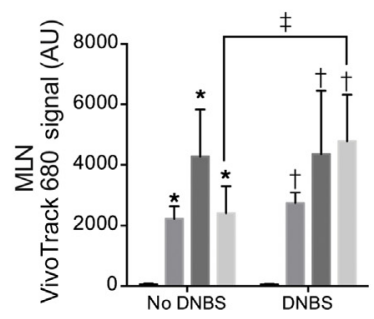

$\mathbf{F}$

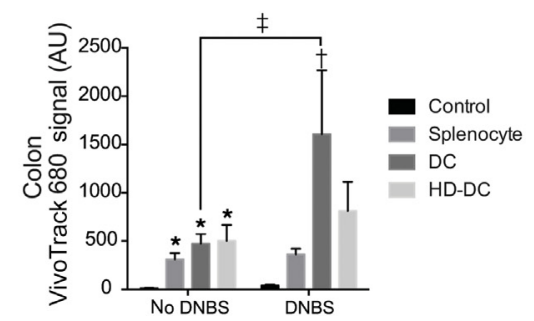

Figure 1 Localization of transferred cells. Noninvasive whole-body imaging was performed on BALB/C mice that received splenocytes, dendritic cells (DCs), and Hymenolepis diminuta antigen-treated (HD)-DCs $\left(2 \times 10^{6}\right.$ i.p.) labeled with VivoTrack 680 dye (PerkinElmer, Waltham, MA); some animals received dinitrobenzene sulfonic acid (DNBS; $3 \mathrm{mg}$ i.r.) 48 hours after cell transfer. A: Representative composites of fluorescence overlaid onto reflectance and X-ray images of ventrally placed mice, 5 days after cell transfer. B: Representative images of fluorescence overlaid onto reflectance images of organs removed 5 days after cell transfer (72 hours after DNBS challenge). C: Representative images of fluorescence overlaid onto reflectance images of the mesenteric lymph nodes (MLNs) and gastrointestinal tract. D-F: Quantification of fluorescence signal of the spleen, MLNs, and colon, respectively. Data are expressed as means \pm SEM (D-F). $n=3$ (naïve DCs); $n=4$ (HD-DCs, DCs + DNBS, HD-DCs + DNBS); $n=5$ (control, DNBS, splenocytes + DNBS); $n=7$ (splenocytes), all from one to two experiments. ${ }^{*} P \leq 0.05$ versus negative control (one-way analysis of variance with Dunnett posttest); ${ }^{\dagger} P \leq 0.05$ versus positive control (one-way analysis of variance with Dunnett posttest); ${ }^{\ddagger} P \leq 0.05 \mathrm{DC}$ versus DC + DNBS, or HD-DC versus HD-DC + DNBS (one-way analysis of variance with Sidak posttest). AU, arbitrary fluorescence units. 
$U$-test or the Kruskal-Wallis test with Dunn posttest. For macroscopy and histology damage scores, analyses were conducted in all DNBS-treated groups; all other analyses included the negative control. Analyses were conducted with Prism software version 6.0 (GraphPad Software, La Jolla, CA).

\section{Results}

Adoptively Transferred HD-DCs Localize to the Spleen, MLN, and Colon, with Enhanced Recruitment in DNBS Colitis

To determine where HD-DCs exert their effect, a fluorescent lipophilic membrane dye was used to mark and then visualize the localization of i.p.-injected cells. Whole-body imaging of control or DNBS-treated mice displayed no detectable fluorescence, with the exception of a small signal in the cecum likely due to residual food (Figure 1, A-C). In contrast, a consistent fluorescence signal was obvious in the peritoneal cavity of mice that received labeled cells 1 to 4 days (not shown) and 5 days (Figure 1A) after cell transfer. A faint signal was detected in the lungs and occasionally the kidneys, with a strong signal in the liver.

Notable fluorescence occurred in the spleen, MLNs, and gastrointestinal tract of mice that received labeled DCs or HD-DCs (Figure 1, B and C), with the pattern and intensity of fluorescence being similar in both cell types under noninflamed (ie, no DNBS) and colitic (DNBS-treated) conditions (Figure 1, D-F). Statistical comparisons revealed that recruitment of DCs and HD-DCs to the spleen was significantly enhanced in mice with colitis (Figure 1D); HD-DC recruitment to the MLNs was similarly enhanced in DNBS-treated mice relative to recruitment under noninflamed conditions (Figure 1E). Treatment with DNBS increased the recruitment of only DCs, not HD-DCs, to the colon relative to healthy recipient mice (Figure $1 \mathrm{~F}$ ).

\section{HD-DC Suppression of Colitis Is Ccr7 Dependent}

In a prophylactic regimen, HD-DCs significantly reduced the severity of DNBS-induced disease ${ }^{18}$; here those observations were extended by showing enhanced recovery from colitis when the HD-DCs were given immediately after the DNBS (Supplemental Figure S1). Given that i.p.-administered HD-DCs migrate to the spleen and MLNs in recipients, with greater localization to these organs in DNBS-treated mice, the importance of lymphatic recruitment in HD-DC suppression of colitis was assessed. Ccr7 plays a key role in DC migration to SLOs, via chemokine (C-C motif) ligand (Ccl) 19 and $\mathrm{Ccl} 21$, which are constitutively expressed by endothelial cells of lymphatic vessels, high endothelial venules, and stromal cells in the T-cell zone. Proinflammatory cytokines increase $\mathrm{Ccl} 21$ expression to enhance the migration efficiency of DCs to SLOs. ${ }^{27}$ Fluorescence quantification of whole spleens revealed a slightly reduced signal among
$\mathrm{Ccr}^{-1-}$ HD-DC recipients, relative to WT controls $(P=0.11)$ (Figure 2, A and B). A greater proportion and total number of VivoTrack $680^{+}$cells were detected in splenocytes isolated from mice receiving WT HD-DCs relative to $\mathrm{Ccr} 7^{-1-}$ HD-DCs (Figure 2C). Whole-organ imaging of MLNs and colons revealed no significant difference in fluorescence intensity between WT and $\mathrm{Ccr} 7^{-/-}$HD-DC recipients (data not shown). The absence of Ccr7 on the DCs abrogated the protection against DNBS-induced colitis afforded by HD-DCs (Figure 2, D-F). Non-worm-antigen-treated $\mathrm{Ccr} 7^{-1-}$ or MHC II ${ }^{-l-}$ DCs did not affect the severity of colitis and so these controls were not included in subsequent analyses [mean \pm SEM disease activity scores: DNBS, $6.4 \pm 1.1(\mathrm{n}=$ 4); DNBS + $\mathrm{Ccr}^{-1-}$ DCs, $5.9 \pm 0.5(n=3)$; and $\mathrm{DNBS}+\mathrm{MHC} \mathrm{II}^{-1-}$ DCs, $\left.7.8 \pm 0.4(n=4)\right]$. ConcanavalinA stimulation of splenocytes isolated from recipients of WT HD-DCs, but not $\mathrm{Ccr} 7^{-1-}$ HD-DCs, resulted in increased splenic Il-4 (Figure 2G) and elevated Il-10 (Figure 2H), consistent with previous findings. ${ }^{18}$

\section{HD-DCs Drive a Th2 Immune Response in the Spleen and MLNs of Recipient Mice}

Treatment with HD-DCs evoked a significant increase in the proportion of $\mathrm{Cd} 4^{+} \mathrm{Gata}-3^{+} \mathrm{T}$ cells in the spleen and MLNs of recipients. Changes in the proportion of Foxp $3^{+}$ cells were not observed: Gata-3 was induced in the Foxp3 $3^{-}$ population after WT HD-DC treatment, indicating the induction of a classic Th2 response, whereas levels of Foxp $3^{+}$T-regulatory cells remained similar among groups (Figure 3, A-C). In vitro stimulated splenocytes from HDDC recipients synthesized significantly higher levels of Il4, with Il-10 also being increased but failing to reach statistical significance in this set of mice (Figure 3D). Mitogen-stimulated splenocytes from HD-DC recipients are not compromised in their capacity to produce interferon- $\gamma$ or tumor necrosis factor $\alpha^{18}$; similar results were observed and additionally it was found that splenocyte output of Il17 was not different between mice treated with DCs or HD-DCs ( $n=3$ to 4 ; data not shown). [Analysis of cytokines (both protein and mRNA) in colonic homogenates yielded inconsistent results ( $n=4$ to 7 ; data not shown), as has been our experience with this model in the past (personal observations)]. None of the other $\mathrm{Cd} 4^{+} \mathrm{T}$-cell compartments in the spleen or MLNs (eg, ROR $\gamma$ t, T-bet) were significantly different between the experimental groups, although the proportion of $\mathrm{Cd}^{+} \mathrm{T}$ cells was slightly increased in the spleen after HD-DC treatment (Table 1).

\section{Protein-Degraded HD Antigens Drive an Anti-Colitic DC}

The induction of Gata- $3^{+} \mathrm{T}$ cells by HD-DCs, coupled with the increased expression of MHC II and Cd80 on HD$\mathrm{DCs},{ }^{18}$ led to the hypothesis that the interaction between HD-DCs and $\mathrm{Cd}^{+}{ }^{+} \mathrm{T}$ cells operates via cognate MHC II-T- 
A
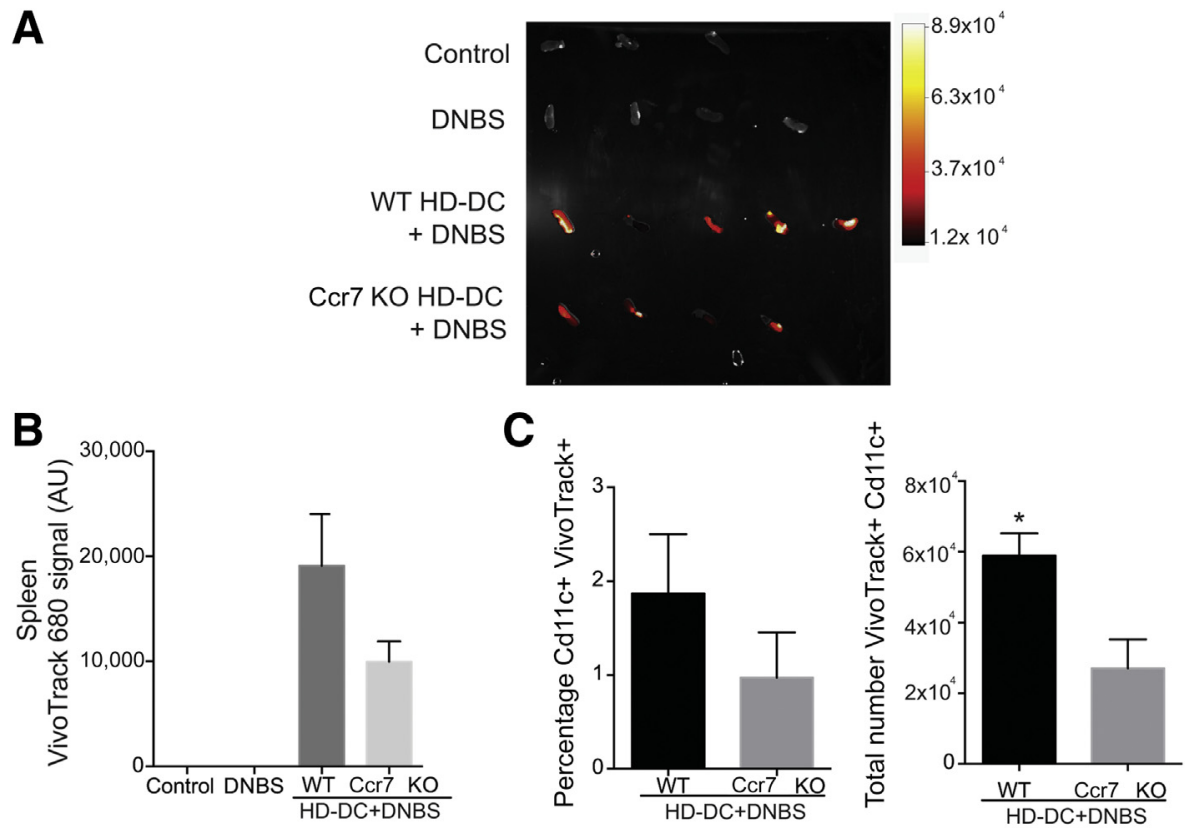

D
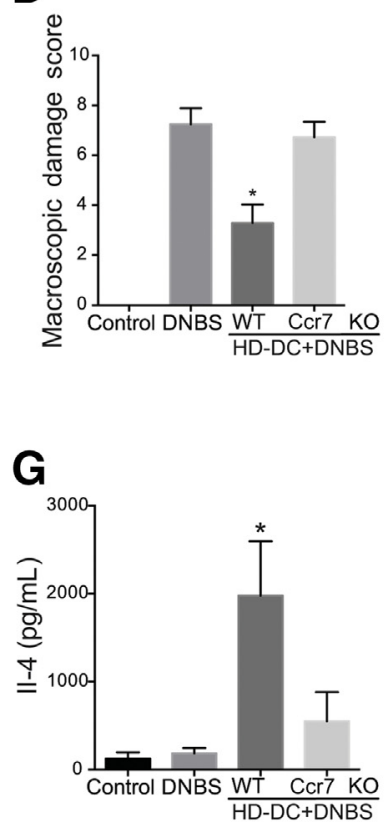

E

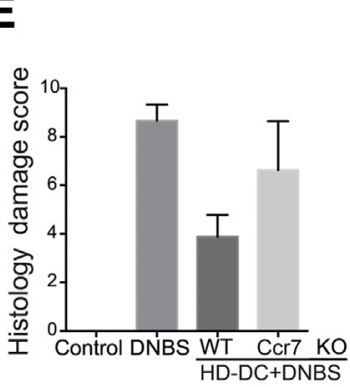

F Control

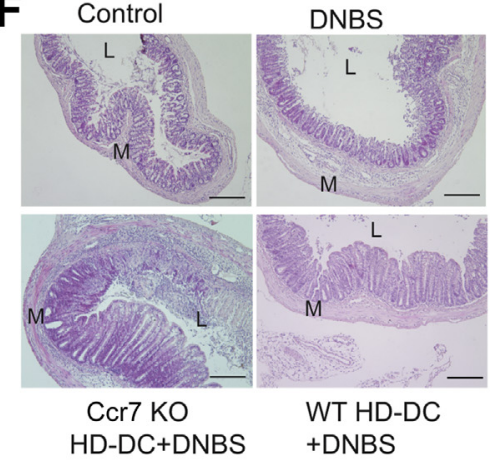

H

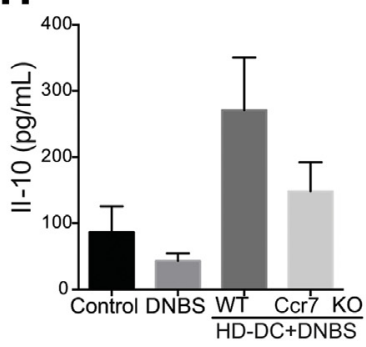

Figure 2 Suppression of colitis by Hymenolepis diminuta antigen-treated dendritic cells (HD-DCs) is C-C chemokine receptor type 7 (Ccr7) dependent. Wild-type (WT) or Ccr7 knockout (KO) HD-DCs (C57BL/6 background) stained with VivoTrack 680 dye (PerkinElmer, Waltham, MA) were transferred (2 $\times 10^{6}$ i.p.) to C57BL/6 mice 48 hours before challenge with dinitrobenzene sulfonic acid (DNBS; $4 \mathrm{mg}$ i.r.). A and B: Spleens were removed 72 hours after DNBS challenge, fluorescence images were acquired and overlaid onto reflectance photographs, and the fluorescence signal was quantified. Capped horizontal line indicates $t$-test analysis. C: Flow-cytometric analysis of the percentage and total number of Cd11c $\mathrm{c}^{+}$VivoTrack $680^{+}$splenocytes in recipients of WT HD-DCs and Ccr7 KO HD-DCs. D and E: Disease severity was assessed 72 hours after DNBS challenge via macroscopy and histology damage scores, and analyzed by the Kruskal-Wallis test with Dunn posttest; capped horizontal line indicates $U$ comparison. F: Representative micrographs of hematoxylin and eosin-stained cross sections of colonic tissue. $\mathbf{G}$ and $\mathbf{H}$ : Supernatants from stimulated splenocytes $\left(5 \times 10^{6}, 2 \mu \mathrm{g} / \mathrm{mL}\right.$ concanavalin A, 48 hours) were measured for Il-4 and Il-10 by enzyme-linked immunosorbent assay, and analyzed by a one-way analysis of variance with Tukey posttest. Data are expressed as means \pm SEM. $n=3$ (G and $\mathbf{H}$, control); $n=4$ (C, Ccr7 KO HD-DCS + DNBS; $\mathbf{G}$ and $\mathbf{H}$, DNBS, Ccr7 KO HD-DCs + DNBS); $n=5$ (C, G, and $\mathbf{H}$, WT HD$\mathrm{DCS}+\mathrm{DNBS})$, all from one experiment. ${ }^{*} P \leq 0.05$ (C, two-tailed $t$-test); ${ }^{*} P \leq 0.05$ versus positive control $(\mathbf{G}$ and $\mathbf{H})$. Scale bar $=300 \mu \mathrm{m}$. $\mathrm{AU}$, arbitrary fluorescence units; $\mathrm{L}$, lumen; $M$, muscle.

cell receptor interaction, and therefore would be dependent on intact protein components of the HD extract. Mice injected with DCs pulsed with proteinase K and heat-treated HD antigen were protected from DNBS-induced colitis, as assessed by reduced macroscopic damage (Figure 4A), but did not display increased concanavalin A-induced Il-4 and Il-10 by splenocytes (Figure 4, B and C). The absence of Il-4 and Il-10 production suggested the possibility of an 


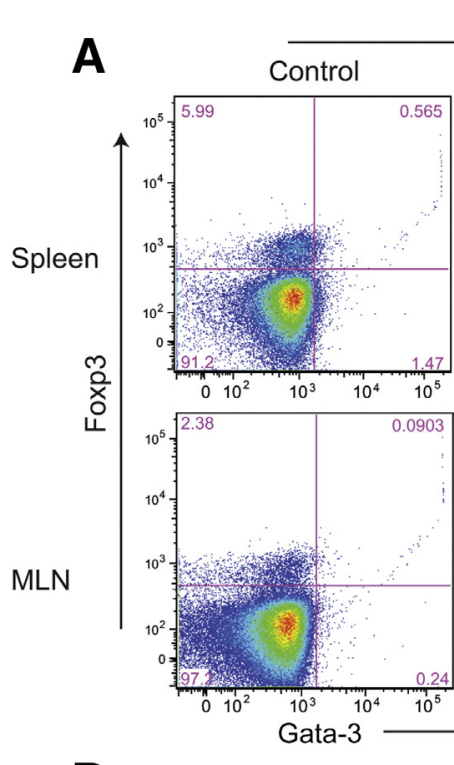

B

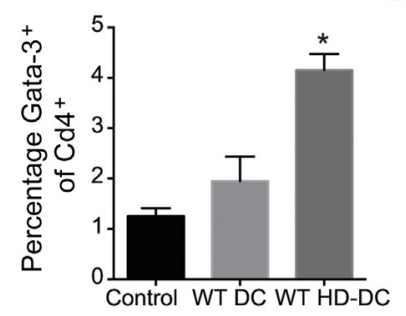

C

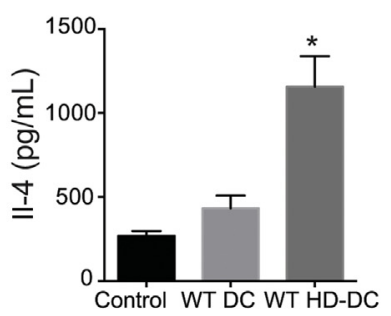

D

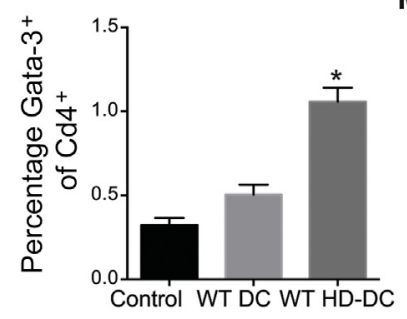

Gated on $\mathrm{Cd}^{+}$
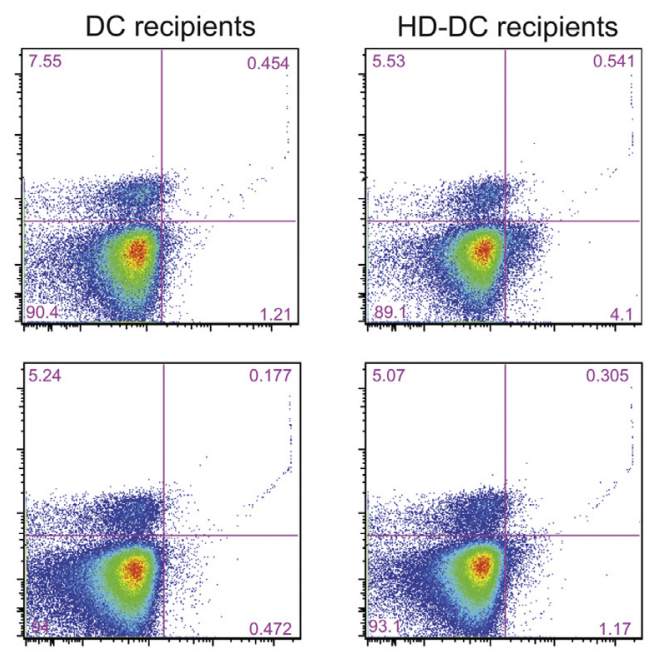

SPLEEN
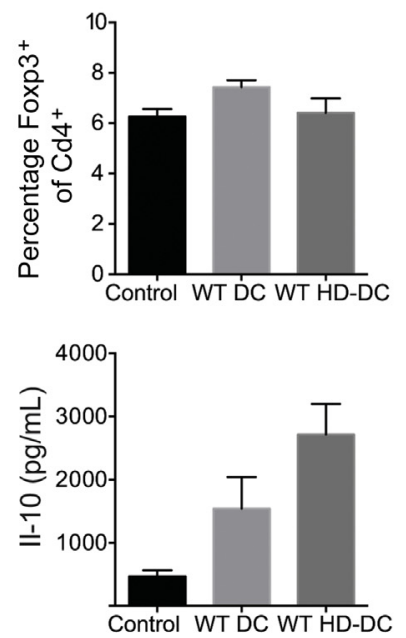

MLN

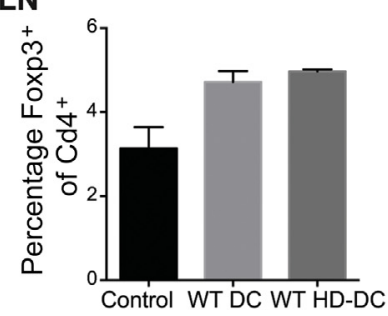

Figure 3 Hymenolepis diminuta antigen-treated dendritic cells (HD-DCs) drive a Th2 immune response in the spleen and mesenteric lymph nodes (MLNs) in recipient mice. A: Representative dot plots of Gata- $3^{+}$ and forkhead box protein P3 (Foxp3) ${ }^{+}$expression in $\mathrm{Cd}^{+} \mathrm{T}$ cells in the spleen and MLNs of control BALB/C mice and mice receiving naïve $D C s$ or $H D-D C s\left(1 \times 10^{6}\right.$ i.p.) are shown. B: Percentage of Gata- $3^{+}$and Foxp $3^{+}$ $\mathrm{Cd}^{+} \mathrm{T}$ cells in the spleen. Data were analyzed by one-way analysis of variance with Sidak posttest between cell-treated groups. Absolute numbers \pm SEM of Gata- $3^{+} \mathrm{Cd}^{+}$splenocytes: control, $6.76 \pm 0.727 \times 10^{5}$; naïve $\mathrm{DCs}, 1.30 \pm$ $0.337 \times 10^{6}$; and HD-DCs, $2.80 \pm 0.384 \times 10^{6}$. Absolute numbers \pm SEM of Foxp $3^{+} \mathrm{Cd4}^{+}$splenocytes: control, $3.64 \pm 0.0727 \times 10^{6} ;$ naïve DCs, $4.93 \pm 0.313 \times 10^{6}$; and HD-DCs, $4.25 \pm$ $0.378 \times 10^{6}$. C: Production of Il-4 and Il-10 in the supernatant of stimulated splenocytes $\left(5 \times 10^{6}, 2 \mu \mathrm{g} /\right.$ $\mathrm{mL}$ concanavalin $\mathrm{A}$, 48 hours) as measured by enzymelinked immunosorbent assay, and analyzed by oneway analysis of variance with Tukey posttest. D: Percentages of Gata- $3^{+}$and Foxp $3^{+} \mathrm{Cd}^{+} \mathrm{T}$ cells in MLNs. Data analyzed by one-way analysis of variance with Sidak posttest between cell-treated groups. Data are expressed as means \pm SEM unless otherwise specified. $n=4$, from one experiment. ${ }^{*} P \leq 0.05$. anti-colitic pathway alternative to the one described previously. ${ }^{18,19}$

\section{MHC II KO HD-DCs Suppress Colitis and Drive Splenic Tgf- $\beta$ Production but Not a Th2 Phenotype}

To further test the requirement for cognate MHC II-Tcell receptor interaction in the HD-DC-initiated suppression of colitis, MHC $\mathrm{II}^{-/-}$DCs were used. Delivery (i.p.) of WT and $\mathrm{MHC}^{\mathrm{II}^{-/-}} \mathrm{HD}-\mathrm{DC}$ resulted in virtually identical suppression of DNBS-induced colitis (Figure 5, A-C), yet MHC $\mathrm{II}^{-/-}$HD-DCs did not elicit increases in splenic Il-4 and Il-10, indicating a reduced Th2 response (Figure 5, D and E). Also, $\mathrm{Cd} 4{ }^{+} \mathrm{Gata}_{-}{ }^{+}$T-cell concentration was not increased in the spleen and MLNs of naïve mice given MHC $\mathrm{II}^{-1-}$ HD-DCs (Figure 6 and Table 2). However, a small but significant increase in Foxp $3^{+} \mathrm{Helios}^{-}$cells was observed in the MLNs of MHC $\mathrm{II}^{-/-}$HD-DC recipients. 
Table 1 T-Cell Phenotype in Mice Receiving WT HD-DCs

\begin{tabular}{|c|c|c|c|c|c|c|c|c|}
\hline \multirow[b]{2}{*}{ Study group } & \multirow[b]{2}{*}{$\mathrm{Cd} 8, \%$} & \multirow[b]{2}{*}{$\mathrm{Cd} 4, \%$} & \multicolumn{2}{|l|}{$\mathrm{Cd4}^{+}$cells } & \multicolumn{2}{|c|}{$\mathrm{Cd}^{+}{ }^{+}$oxp $^{+}$cells } & \multicolumn{2}{|l|}{$\mathrm{Cd}^{+}{ }^{+}$cells } \\
\hline & & & Gata-3, \% & Foxp3, \% & Helios $^{-}, \%$ & Helios $^{+}, \%$ & T-bet, \% & ROR $\gamma t, \%$ \\
\hline \multicolumn{9}{|l|}{ Spleen } \\
\hline WT DCs & $10.64 \pm 0.50$ & $18.48 \pm 0.78$ & $1.95 \pm 0.49$ & $7.43 \pm 0.27$ & $1.96 \pm 0.05$ & $5.92 \pm 0.25$ & $1.82 \pm 0.28$ & $0.55 \pm 0.075$ \\
\hline WT HD-DCs & $12.05 \pm 0.54$ & $22.78 \pm 0.81^{*}$ & $4.15 \pm 0.32^{*}$ & $6.41 \pm 0.57$ & $1.69 \pm 0.05$ & $5.11 \pm 0.52$ & $1.70 \pm 0.29$ & $0.49 \pm 0.10$ \\
\hline \multicolumn{9}{|l|}{ MLNs } \\
\hline WT HD-DCs & $28.1 \pm 0.85$ & $44.83 \pm 0.80$ & $0.73 \pm 0.05^{*}$ & $3.14 \pm 0.03$ & $2.02 \pm 0.06$ & $3.20 \pm 0.04$ & $0.45 \pm 0.10$ & $0.40 \pm 0.06$ \\
\hline
\end{tabular}

C57BL/6 mice received $1 \times 10^{6}$ naïve WT DCs or HD-DCs in phosphate-buffered saline; controls received an equal volume of vehicle. All cells are gated on the viable lymphocyte population, before doublet exclusion. Gata-3 and Foxp3 populations are expressed as the percentage of $\mathrm{Cd}^{+}{ }^{+}$cells, whereas T-bet and $\mathrm{ROR} \gamma \tau$ are expressed as the percentage of $\mathrm{Cd}^{+}{ }^{+} \mathrm{Gata}-3^{-} \mathrm{Foxp}^{-}$cells. Data are expressed as means $\pm \mathrm{SEM}$.

${ }^{*} P<0.05$ versus WT DC treatment (one-way analysis of variance with Sidak posttest); $n=4$, from one experiment.

DCs, dendritic cells; Foxp3, forkhead box protein P3; HD, Hymenolepis diminuta antigen treated; MLNs, mesenteric lymph nodes; T-bet, T-box protein expressed in T cells; WT, wild type.

Although only the adoptive transfer of WT HD-DCs drove the production of Il-4 and Il-10 in concanavalin A-stimulated splenocytes, the transfer of $\mathrm{MHC} \mathrm{II}^{-1-} \mathrm{HD}-$ DCs significantly increased the synthesis of Tgf- $\beta$ by concanavalin A-stimulated splenocytes relative to recipients of naïve WT, naïve MHC $\mathrm{II}^{-1-}$, or HD-DC WT DCs (Figure 7). In contrast, in vitro co-culture of splenic $\mathrm{Cd}^{+} \mathrm{T}$ cells with HD-DCs did not consistently result in an increase in Tgf- $\beta$ production, suggesting the absence of a key factor in vitro that was available to the cells in vivo (data not shown).

To test whether protection by $\mathrm{MHC} \mathrm{II}^{-/-}$HD-DCs was mediated by $\mathrm{Cd}^{+}{ }^{+} \mathrm{T}$ cells, as was the case with WT HD-DCs,${ }^{18} \mathrm{Cd} 4^{+} \mathrm{T}$ cells isolated from the spleen of $\mathrm{MHC} \mathrm{II}^{-1-}$ HD-DC-treated mice 5 days after cell transfer were administered i.p. to naïve mice that were immediately challenged with DNBS (Figure 8A). The adoptive transfer of MHC II ${ }^{-l-}$ HD-DC-educated $\mathrm{Cd} 4^{+}$ $\mathrm{T}$ cells significantly attenuated the severity of colitis, as shown by reduced damage on macroscopy (Figure 8B) and histology (Figure 8, C and D). The T-cell transfer did not influence the production of Il-4, Il-10, or Tgf- $\beta$ by concanavalin A-stimulated splenocytes from the recipient mice (Figure 8, E-G). Supportive of these data, the transfer of $\mathrm{MHC} \mathrm{II}^{-/-}$HD-DC to recombinationactivating gene $1^{-1-}$ mice did not result in an amelioration of DNBS-induced colitis (5 $\mathrm{mg}$ i.r., 72 hours) [mean \pm SD disease activity scores: control, $0 \pm 0$ $(n=3)$; DNBS, $6.7 \pm 2.7(n=3)$; DNBS $+\mathrm{MHC} \mathrm{II}^{-1-}$ HD-DC, two of four mice required early euthanization because of disease severity and the other two had disease activity scores of 8.2 and 4.5 ].
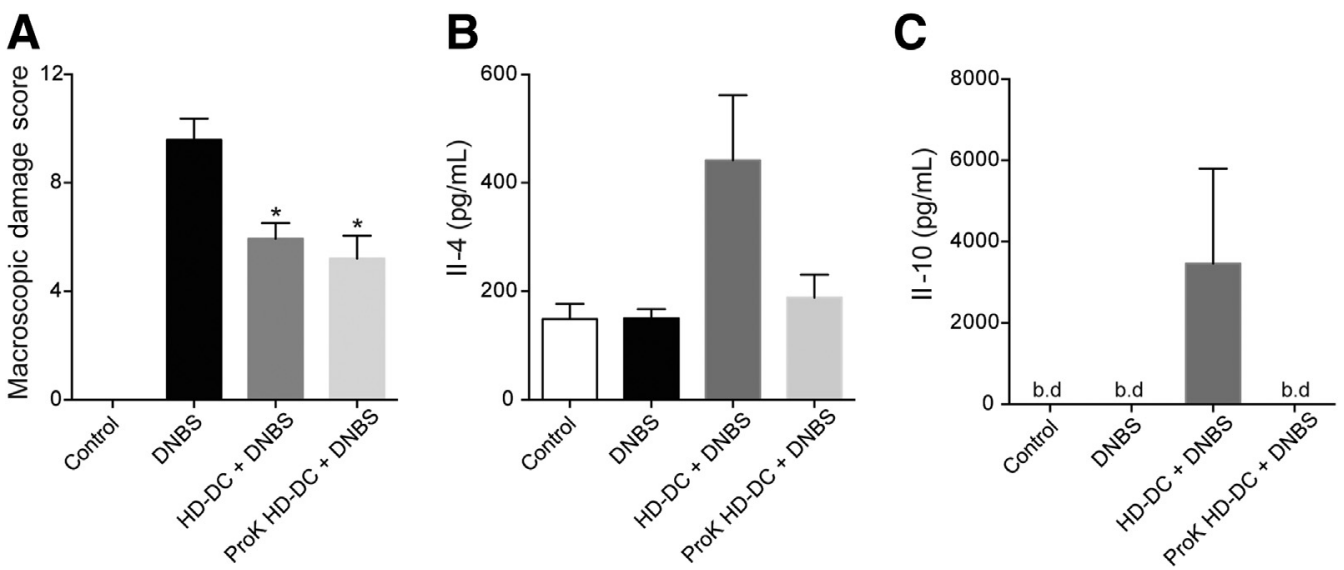

Figure 4 Proteinase $\mathrm{K}$ (proK)- and heat-degraded Hymenolepis diminuta (HD) antigens drive an anti-colitic dendritic cell (DC). BALB/C mice were administered $1 \times 10^{6} \mathrm{DCs}$ i.p. previously treated with intact HD extract, or boiled and proK-digested HD extract ( $\left.100 \mu \mathrm{g} / \mathrm{mL}, 24 \mathrm{hours}\right)$, and challenged with dinitrobenzene sulfonic acid (DNBS) 48 hours later. A: Macroscopic damage scores were assessed 72 hours later, and analyzed by Kruskal-Wallis test with Dunn posttest. B and C: Splenocytes were stimulated $\left(5 \times 10^{6}, 2 \mu \mathrm{g} / \mathrm{mL}\right.$ concanavalin A, 48 hours $)$ and supernatants assessed for levels of Il-4 and Il-10 by enzymelinked immunosorbent assay. Data are expressed means \pm SEM. $n=3$ (B and C, control, DNBS, from one experiment); $n=5$ (B and C, HD-DCs + DNBS, proK HD-DCs + DNBS, from one experiment); $n=6$ (A, control, from two experiments); $n=7$ (A, DNBS, from two experiments); $n=9$ (A, HD-DCs + DNBS, proK HD-DCs + DNBS, from two experiments). ${ }^{*} P \leq 0.05$ versus positive control. b.d., below detection threshold. 
A

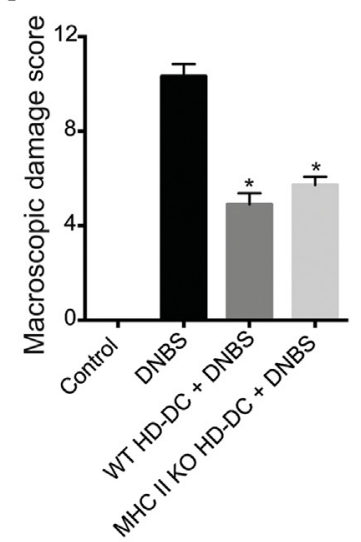

C
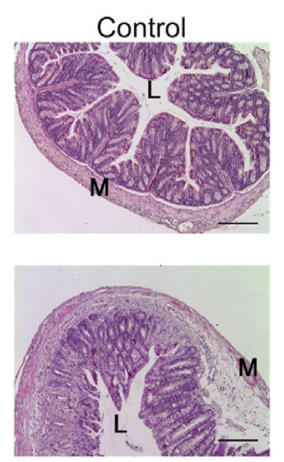

WT

HD-DC+DNBS

D

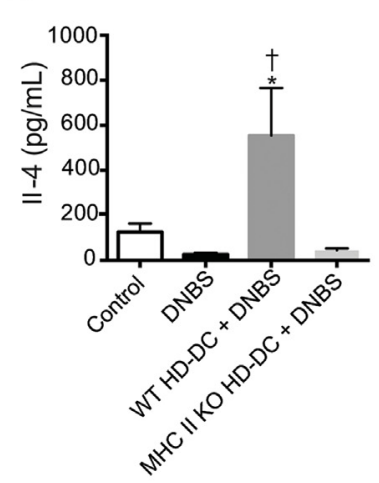

B

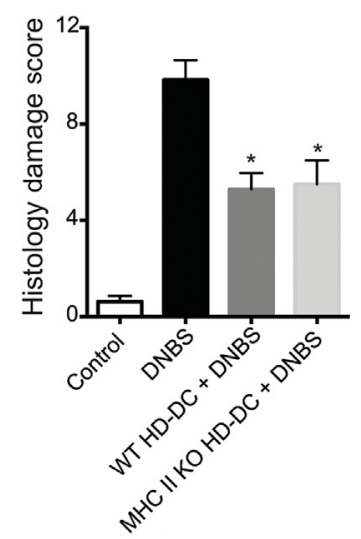

Intact HD Glycans Are Required to Induce Anti-Colitic WT and MHC II KO DCs

Helminth-derived glycans modify the immunomodulatory properties of DCs, ${ }^{28-30}$ as determined by the ablation of the bioactivity in helminth-derived extracts by treatment with sodium metaperiodate. ${ }^{31-33}$ When WT DCs (Figure 9, $\mathrm{A}-\mathrm{C}$ ) or $\mathrm{MHC} \mathrm{II}^{-/-}$DCs (Figure 9, F-H) were exposed to sodium metaperiodate-treated HD extract, both cell types failed to inhibit DNBS-induced colitis (adoptive transfer of DCs pulsed with sham-treated worm extract reduced the severity of DNBS-induced tissue damage). In accordance with these indices of colonic disease, WT sodium metaperiodate-treated HD-DCs did not elicit an increase in Il-4 or Il-10 from recipient splenocytes (Figure 9, $\mathrm{D}$ and E). As before (Figure 5, D and E), MHC $\mathrm{II}^{-I-} \mathrm{HD}$ DCs did not elicit a splenic Il-4 response in recipient mice (Figure 9I) independent of sodium metaperiodate treatment, although in this instance there was a moderate increase in splenic Il-10 above that of DNBS-only treated mice (Figure 9J). ${ }^{18}$

\section{Discussion}

Helminth and cellular immunotherapy are being assessed in preclinical and clinical trials in inflammatory disease, including inflammatory bowel disease. ${ }^{8}$ Combining these approaches, we previously showed that HD-DCs protected mice from DNBS-induced colitis. ${ }^{18}$ Expanding on this finding, the current data support three main conclusions. First, the expression of Ccr7 and hence homing to SLOs is important for the maximum anti-colitic effect of HD-DCs. Second, the suppression of colitis initiated by the WT HD-DCs promotes splenic $\mathrm{Cd} 4^{+} \mathrm{Gata}^{+}{ }^{+} \mathrm{Th} 2$ cells; yet, in the absence of MHC II, an alternative anti-colitic pathway emerges that is independent of Th2 immunity but is transferred by $\mathrm{Cd}^{+}{ }^{+}$splenic T cells. Finally, a key molecule(s) in the worm extract that facilitates the DC immunoregulatory/ anti-colitic phenotype is a heat- and proteinase $\mathrm{K}$-insensitive glycan(s).

Adoptive transfer of $\mathrm{T}$ cells, DCs, macrophages, and mesenchymal stem cells suppresses inflammation in a celland disease-specific manner via activity in the target organ, SLOs, or the peritoneum. ${ }^{15,26,34-36}$ Immunolocalization revealed HD-DCs preferentially trafficked to the spleen, MLN, and colon of recipient mice; recruitment of HD-DCs to these SLOs, but not the colon, was significantly enhanced in colitic mice. The functional significance of the high level of fluorescence observed in the liver was not evaluated but likely reflects drainage from the peritoneum. ${ }^{26,37}$ Considering its role as an immunologic organ, ${ }^{38}$ it cannot be ruled out that DC activity in the liver could have anti-colitic consequences; however, previous studies revealed that HD-DCs drive production of Th2 cytokines by splenocytes, and that $\mathrm{Cd}^{+}$splenocytes from recipient mice block 

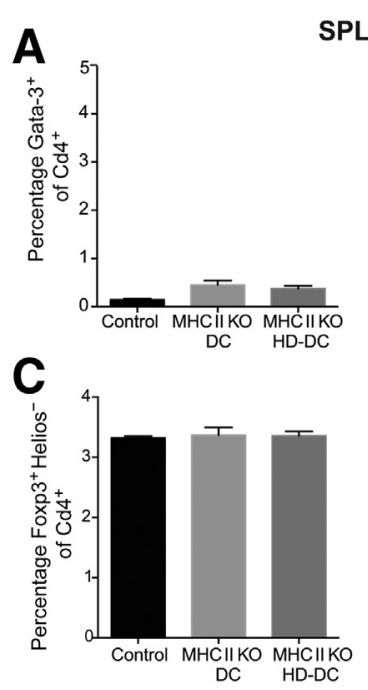

SPLEEN
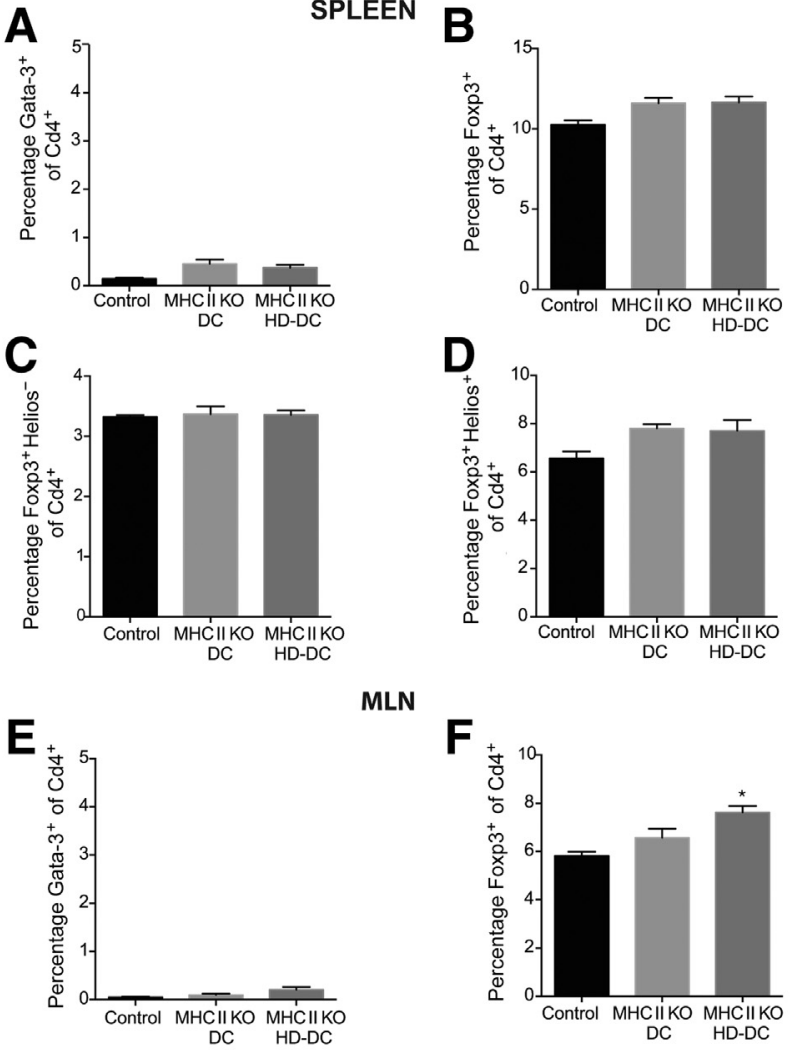

MLN
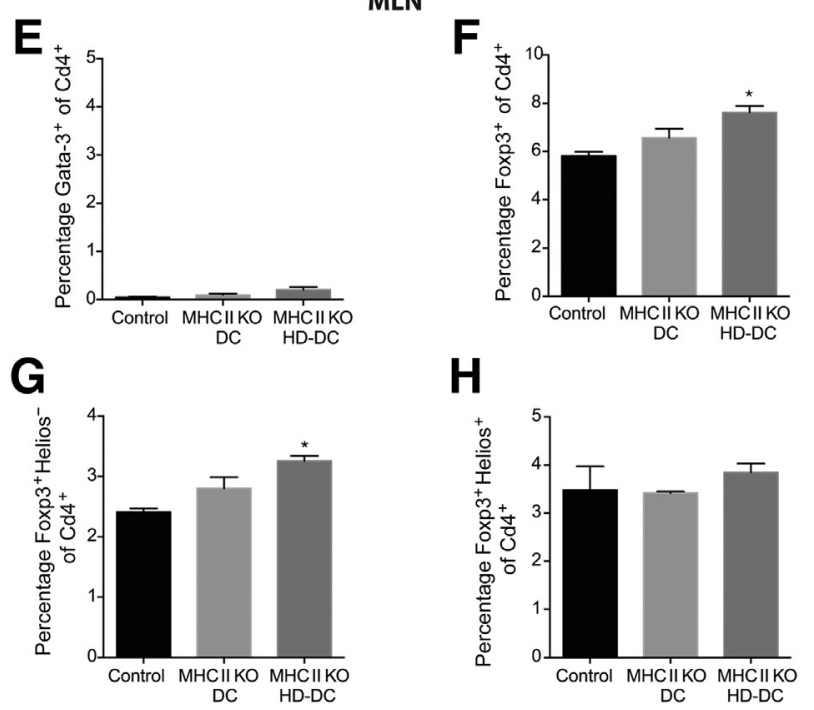

H

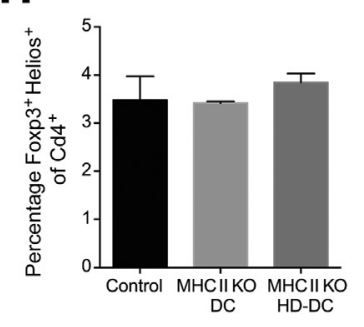

Figure 6 Major histocompatibility complex class II knockout (MHC II KO) Hymenolepis diminuta antigen-treated dendritic cells (HD-DCs) do not drive Th2 response in recipients. $\mathbf{A}-\mathbf{H}$ : Flow-cytometric quantification of the percentages of $\mathrm{Gata}-3^{+}$, forkhead box protein P3 (Foxp-3) ${ }^{+}$, Foxp $3^{+}$Helios $^{-}$, and Foxp $3^{+}$Helios $^{+} \mathrm{Cd4}^{+}$cells in the spleen (A-D) and mesenteric lymph nodes (MLNs) $(\mathbf{E}-\mathbf{H})$ of $\mathrm{C} 57 \mathrm{BL} / 6$ mice receiving MHC II KO HD-DCs $\left(1 \times 10^{6}\right.$ i.p. $) 5$ days previously. Mean \pm SEM absolute numbers of Gata- $3^{+} \mathrm{Cd}^{+}$splenocytes: control, $1.04 \pm 0.357 \times 10^{5}$; naïve $\mathrm{MHC} \mathrm{II}^{-/}-$ DCs, $3.53 \pm 0.503 \times 10^{5}$; and $\mathrm{MHC} \mathrm{II}^{-/-}$HD-DCs, $2.39 \pm 0.341 \times 10^{5}$. Mean \pm SEM absolute numbers of $\mathrm{Foxp}^{+} \mathrm{Cd}^{+}$splenocytes: control, $7.43 \pm 1.77 \times 10^{6}$; naïve MHC II ${ }^{-/-}$DCs, $9.48 \pm 0.922 \times 10^{6} ;$ and MHC II $-/-$ HD-DCs, $8.09 \pm 1.67 \times 10^{6}$. Data are expressed as means \pm SEM. $n=4$ (control); $n=5$ (HD-DC, MHC II KO HD-DCs), from one experiment. ${ }^{*} P<0.05$ (one-way analysis of variance with Sidak posttest between celltreated groups).

colitis, ${ }^{18}$ suggesting that nonhepatic mechanisms are responsible for disease suppression.

The absence of increased HD-DC recruitment to the colon in DNBS-induced inflammation suggests that homing to the gut is not as important as recruitment to SLOs in this model, although this remains to be tested. Since HD-DCs require adaptive immune responses in recipients to suppress colitis, ${ }^{18,26}$ recruitment of HD-DCs to SLOs to suppress colitis is not surprising. Ccr7 is important for DC migration to $\mathrm{SLOs},{ }^{27}$ directing chemotaxis via a $\mathrm{G}$ protein and mitogen-activated protein kinase-dependent process, while mobilizing a Rho/protein-tyrosine kinase 2/cofilindependent pathway to control the speed of cell migration. ${ }^{39}$ Adoptive transfer of $\mathrm{Ccr}^{-/-} \mathrm{HD}-\mathrm{DC}$ failed to attenuate DNBS-induced colitis, yet the reduced homing of $\mathrm{Ccr} 7^{-1-}$ HD-DCs to the spleen was not statistically significant, and recruitment of WT and $\mathrm{Ccr}^{-1-}$ HD-DCs to the MLN was equivalent. However, deletion of Ccr7 does not fully impair DC migration to SLOs. ${ }^{40,41}$ In the absence of Ccr7, DCs have been reported to increase chemotaxis to the C-X-C chemokine receptor type 4 ligand Cxcl12; however, as the Cer7 ligand Ccl19 is approximately 10-fold more potent than Cxcl12, it seems unlikely that HD-DCs lacking Ccr7 would localize in SLOs with the equivalent speed and efficiency as WT HD-DCs. ${ }^{42}$ Thus, the inability of $\mathrm{Ccr}^{-1-}$ HD-DCs to ablate the severity of DNBS-induced colitis in our study is in accordance with recruitment to SLOs (specifically the spleen) being of central importance in the anticolitic effect of HD-DCs. These findings, however, do not discount the potential importance of local cytokine responses; the kinetics of such responses and the source of these cytokines within the lamina propria should be considered in future studies.

HD-DCs do not attenuate colitis in T cell-deficient mice, and $\mathrm{Cd} 4^{+} \mathrm{T}$ cells from the spleens of HD-DC-treated mice suppress disease. ${ }^{18}$ Characterizing the T-cell phenotypes induced by HD-DC transfer revealed a significant increase in the proportion of $\mathrm{Gata}^{+}$(Th2 master transcription factor)/Cd4 ${ }^{+}$splenic and MLN T cells in response to HD-DC treatment. In contrast, the expression of neither T-bet, $\operatorname{ROR} \gamma \tau$ (Th1 and Th17 transcription factors, respectively), nor Foxp $3^{+}$in $\mathrm{Cd}^{+}$cells was increased in the SLOs after delivery of HD-DCs. These results are in accordance with studies showing helminth antigen-loaded DCs drive Th2 responses. ${ }^{43-47}$ Others report that helminth-educated DCs can increase the numbers of T-regulatory cells, ${ }^{15,48}$ and Foxp3 mRNA was subtly increased in the colon of mice infected with HD. ${ }^{49}$

Helminths produce immunomodulatory proteins, such as the cathelicidin-like peptides from the trematode Fasciola hepatica, which impede antigen processing and presentation by macrophages. ${ }^{50}$ Sensitivity to boiling and enzymatic digestion (typically trypsin or proteinase $\mathrm{K}$ ) are often used to characterize proteinaceous helminth-derived immunomodulatory molecules. This approach revealed protein- and heat-sensitive molecules from Onchocera volvulus and HD, respectively, which suppressed T-cell proliferation ${ }^{41,51,52 \text {; }}$ schistosome egg antigen proteins, which induced DC secretion of Il-1 $\beta^{53}$; and Nippostrongylus brasiliensis antigens, which, when applied to DCs, drove Th2 responses in recipient mice. ${ }^{46,54}$ Although DCs treated with heat- and proteinase $\mathrm{K}$-degraded $\mathrm{HD}$ extract retained their ability to suppress DNBS-induced colitis, they did not enhance 
Table 2 T-Cell Phenotype in Mice Receiving MHC II KO HD-DCs

\begin{tabular}{|c|c|c|c|c|c|c|c|c|}
\hline \multirow[b]{2}{*}{ Study group } & \multirow[b]{2}{*}{$\mathrm{Cd} 8, \%$} & \multirow[b]{2}{*}{$\mathrm{Cd} 4, \%$} & \multicolumn{2}{|l|}{$\mathrm{Cd}^{+}$cells } & \multicolumn{2}{|c|}{$\mathrm{Cd}_{4}{ }^{+} \mathrm{Foxp}^{+}$cells } & \multicolumn{2}{|l|}{$\mathrm{Cd}^{+}$cells } \\
\hline & & & Gata-3, \% & Foxp3, \% & Helios $^{-}, \%$ & Helios $^{+}, \%$ & T-bet, \% & ROR $\gamma \mathrm{t}, \%$ \\
\hline \multicolumn{9}{|l|}{ Spleen } \\
\hline KO DCs & $13.05 \pm 0.28$ & $20.80 \pm 0.58$ & $0.45 \pm 0.09$ & $11.60 \pm 0.33$ & $3.37 \pm 0.13$ & $7.81 \pm 0.18$ & $4.61 \pm 0.61$ & $2.10 \pm 0.49$ \\
\hline KO HD-DCs & $13.92 \pm 0.54$ & $21.10 \pm 0.79$ & $0.37 \pm 0.06$ & $11.66 \pm 0.36$ & $3.35 \pm 0.07$ & $7.71 \pm 0.44$ & $4.3 \pm 0.38$ & $0.98 \pm 0.30$ \\
\hline \multicolumn{9}{|l|}{ MLNs } \\
\hline WT HD-DCs & $27.64 \pm 0.80$ & $40.06 \pm 1.17$ & $0.21 \pm 0.06$ & $7.62 \pm 0.27^{*}$ & $3.26 \pm 0.09 *$ & $3.85 \pm 0.18$ & $0.68 \pm 0.24$ & $0.72 \pm 0.14$ \\
\hline
\end{tabular}

C57BL/6 mice received $1 \times 10^{6}$ naïve MHC II KO DCs or HD-DCs in phosphate-buffered saline; controls received an equal volume of vehicle. All cells are gated on the viable lymphocyte population, before doublet exclusion. Gata-3 and Foxp3 populations are expressed as the percentage of Cd4 ${ }^{+}$cells, whereas T-bet and $\mathrm{ROR} \gamma \tau$ are expressed as the percentage of $\mathrm{Cd4}^{+} \mathrm{Gata}-3^{-} \mathrm{Foxp}^{-}$cells. Data are expressed as means $\pm \mathrm{SEM}$.

${ }^{*} P<0.05$ versus KO DC treatment (one-way analysis of variance with Sidak posttest). $n=4$ (control); $n=5$ (HD-DCS and MHC II KO HD-DCS), all from one experiment.

DCs, dendritic cells; Foxp3, forkhead box protein P3; HD, Hymenolepis diminuta antigen treated; K0, knockout; MHC II, major histocompatibility complex class II; MLNs, mesenteric lymph nodes; T-bet, T-box protein expressed in T cells; WT, wild type.

splenocyte production of Il-4 and Il-10, important cytokines in this model for disease suppression. ${ }^{18,19}$ Adoptive transfer of heat and proteinase $\mathrm{K}$-treated HD-DCs may still be compatible with these cells' activation of Th2 immunity via MHC II interaction with $\mathrm{T}$ cells, since antigenic peptides remained in the helminth extracts; however, the lack of Il-4 and Il-10 responses from splenocytes in mice given boiled + proteinase $\mathrm{K}$-treated HD-DCs suggested an alternative pathway of the suppression of colitis.

Adoptive transfer of $\mathrm{MHC}^{-1-} \mathrm{HD}-\mathrm{DCs}$ unexpectedly resulted in the suppression of DNBS-induced colitis; in separate experiments, the transfer of these cells was accompanied by an increased capacity of isolated splenocytes to produce Tgf- $\beta$, a cytokine that can ameliorate colitis. ${ }^{55,56}$ Helminth induction of Tgf- $\beta$ is not unprecedented. ${ }^{15,57,58}$ However, in vitro co-culture of naïve splenic $\mathrm{Cd}^{+}{ }^{+} \mathrm{T}$ cells and HD-DCs did not result in increased Tgf- $\beta$ (personal observations), suggesting that an environmental factor available to the cells in vivo was absent in vitro. Furthermore, when DNBS was introduced into the model, levels of splenic Tgf- $\beta$ in MHC II KO mice were inconsistent and variable, possibly due to altered Tgf- $\beta$ availability under inflammatory conditions. Consequently, conclusions on the role of Tgf- $\beta$, if any, in the suppression of DNBS-induced colitis by MHC $\mathrm{II}^{-l-}$ HD-DCs would be premature, and an extensive and rigorous series of experiments are required to determine whether this preliminary observation on increased Tgf- $\beta$ is relevant as an alternative pathway of the suppression of colitis in mice given MHC $\mathrm{II}^{-1-}$ HD-DCs. Il-4 and Il-10 signaling is required for WT HD-DCs to inhibit DNBS-induced colitis, ${ }^{18,19}$ so in the absence of either (or both), it is unclear why this alternative pathway of immune suppression is not mobilized. It is likely that the absence of MHC II that is crucial in the activation of the alternative pathway may not be recapitulated by deficiencies in Il-4, Il-10, or their respective receptors.
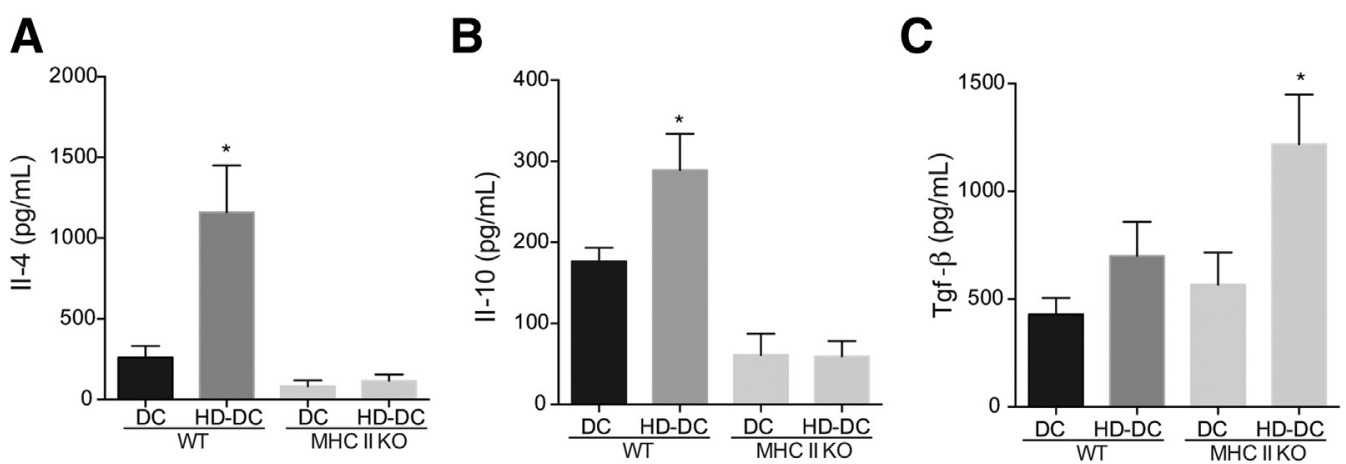

Figure 7 Major histocompatibility complex class II knockout (MHC II KO) Hymenolepis diminuta antigen-treated dendritic cells (HD-DCs) drive splenic transforming growth factor (Tgf)- $\beta$. Wild-type (WT) or MHC II K0 untreated DCs, or HD-DCs (100 $\mu \mathrm{g} / \mathrm{mL})$ were adoptively transferred $\left(1 \times 10^{6} \mathrm{i}\right.$.p.) to C57BL/6 mice. A-C: Splenocytes were isolated 5 days later, stimulated $\left(5 \times 10^{6}, 2 \mu \mathrm{g} / \mathrm{mL}\right.$ concanavalin A, 48 hours), supernatants were collected, and levels of Il-4, Il10 , and Tgf- $\beta$ were measured by enzyme-linked immunosorbent assay and analyzed by one-way analysis of variance with Sidak posttest between the WT HD-DC and MHC II KO HD-DC groups. Data are expressed as means \pm SEM. $n=8$ (MHC II KO naïve DCs); $n=11$ (naïve DCs); $n=16$ (MHC II KO HD-DCs); $n=18$ (HD-DCs), all from three or four experiments. ${ }^{*} P \leq 0.05$. 

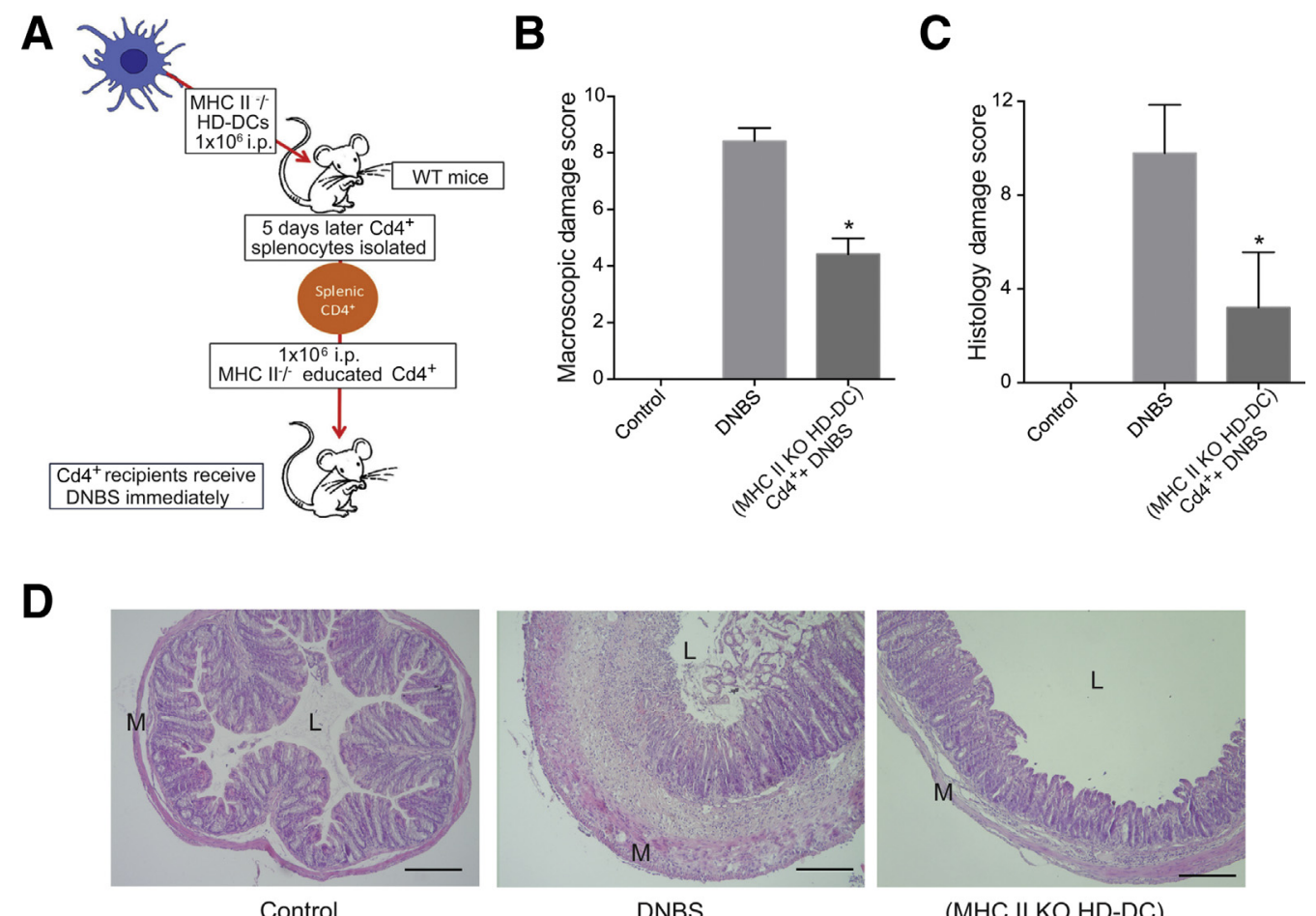

DNBS

(MHC II KO HD-DC)

$\mathrm{Cd} 4^{+}+\mathrm{DNBS}$
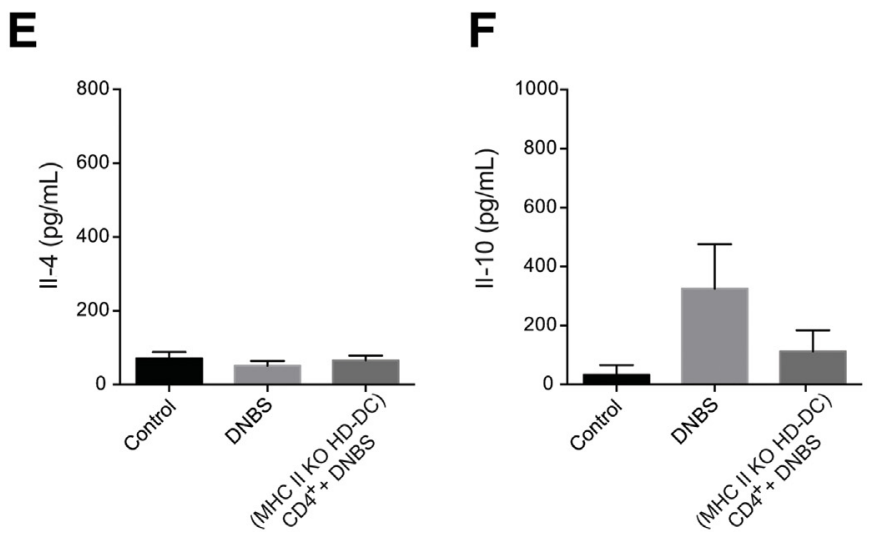

\section{G}

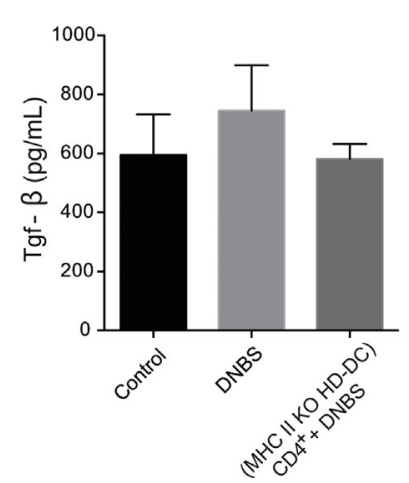

Figure 8 Major histocompatibility complex class II knockout (MHC II KO) Hymenolepis diminuta antigen-treated dendritic cells (HD-DCs) educate an anticolitic $\mathrm{Cd4}^{+}$splenocyte. A: C57BL/6 mice received $\mathrm{Cd}^{+}$splenocytes $\left(1 \times 10^{6}\right)$ from the mice that were given MHC II KO HD-DCs $\left(1 \times 10^{6}\right.$ i.p. $) 5$ days previously, and were immediately challenged with dinitrobenzene sulfonic acid (DNBS) (4 mg i.r.). B and C: Severity of colitis was assessed by macroscopy (B) and histology (C) damage scores, and analyzed by Kruskal-Wallis test with Dunn posttest. D: Representative hematoxylin and eosin-stained cross sections of colonic tissue. E-G: Supernatants of recipient stimulated splenocytes $\left(5 \times 10^{6}, 2 \mu \mathrm{g} / \mathrm{mL}\right.$ concanavalin A, 48 hours) were analyzed for levels of Il-4, Il-10, and

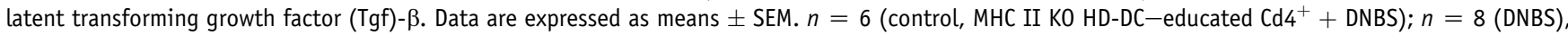
from two experiments. ${ }^{*} P<0.05$ versus positive control. Scale bar $=300 \mu \mathrm{m}$. L, lumen; $\mathrm{M}$, muscle.

Characterization of the effect of MHC II ${ }^{-/-}$HD-DCs revealed that, unlike WT HD-DCs, they failed to induce Gata-3 expression in the spleen or MLNs of recipient mice. MHC $\mathrm{II}^{-1-}$ HD-DCs evoked a small but significant increase in the percentage of $\mathrm{Cd}^{+}{ }^{+} \mathrm{Foxp}^{+}{ }^{+} \mathrm{Helios}^{-}$cells in the MLN, characteristic of peripheral induction of T-regulatory cells, rather than the recruitment of natural T-regulatory cells. ${ }^{59}$ Interestingly, although infection with Heligmosomoides polygyrus similarly resulted in a subtle (approximately 0.13 -fold) increase in colonic $\mathrm{Cd} 4{ }^{+} \mathrm{Foxp}^{+}$ cells, only transfer of colonic $\mathrm{Cd} 4^{+}$cells from $H$. polygyrus-infected, but not control, mice, attenuated colitis. ${ }^{60}$ This finding suggests that helminth parasites (and, by extension, their antigens) have the potential to alter the immunosuppressive capacity of $\mathrm{Foxp}^{+}$cells in the absence of significant proliferation.

WT HD-DCs educate splenic $\mathrm{Cd} 4^{+} \mathrm{T}$ cells that suppress disease.$^{18}$ Remarkably, we found that $\mathrm{Cd} 4^{+}$splenic T cells from recipients of $\mathrm{MHC} \mathrm{II}^{-/-} \mathrm{HD}-\mathrm{DCs}$ significantly attenuated the severity of DNBS-induced colitis in the 
A

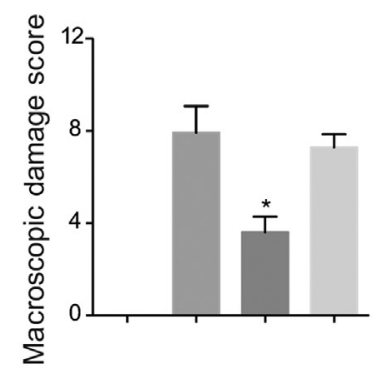

D

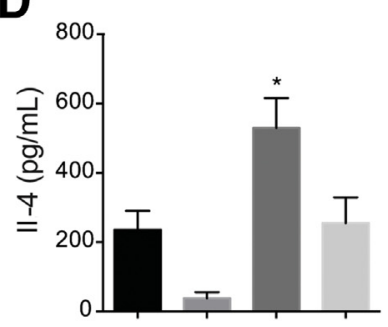

$\mathbf{F}$
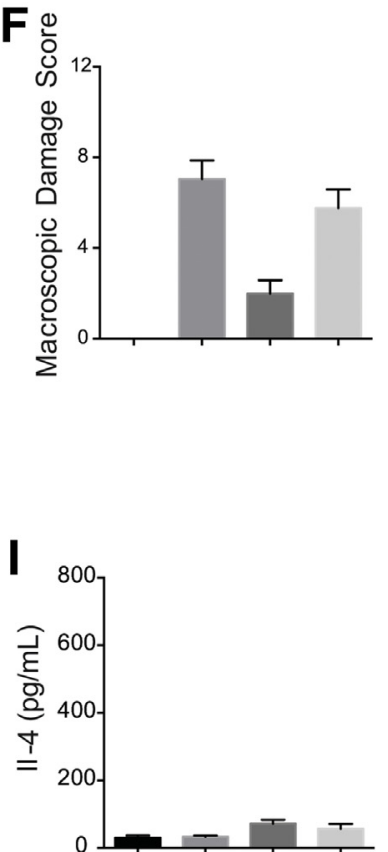

B

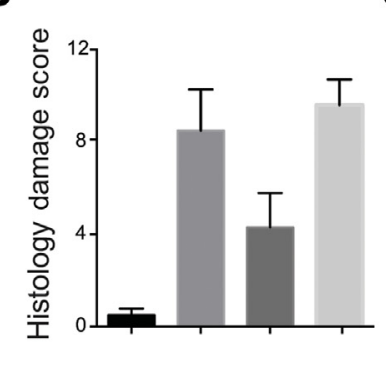

E

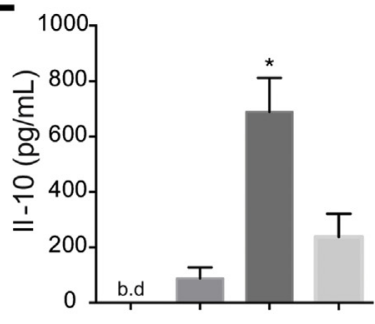

G

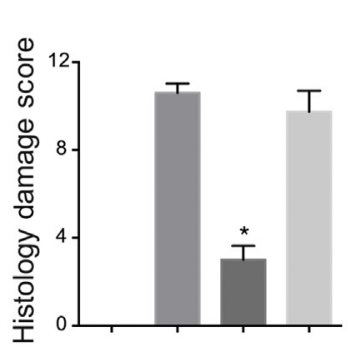

C

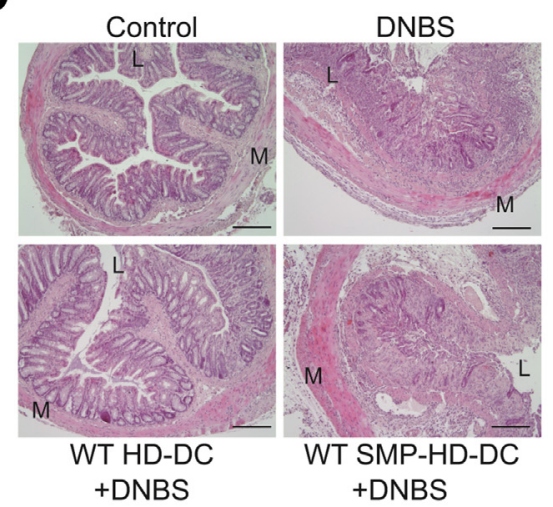

Control

DNBS

WT HD-DC+DNBS

WT SMP-HD-DC+DNBS

H

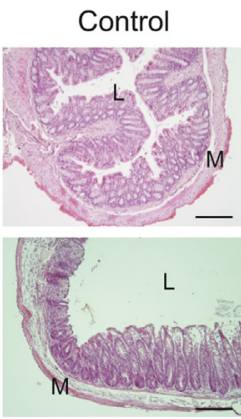

$\mathrm{MHC}$ II KO HD-DC+DNBS

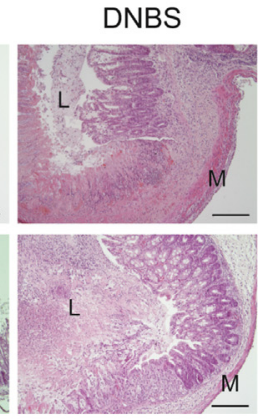

$\mathrm{MHC} \| \mathrm{KO}$

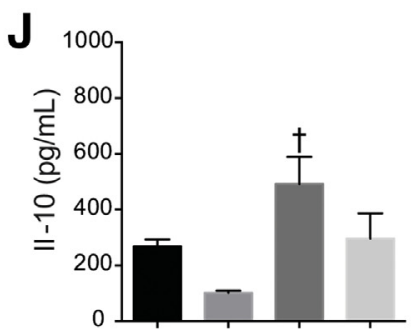

Control

DNBS

MHC II KO HD-DC+DNBS MHC II KO SMP-HD-DC+DNBS

Figure 9 Hymenolepis diminuta (HD)-derived glycans are indispensable for suppression of dinitrobenzene sulfonic acid (DNBS) colitis. Wild-type (WT) dendritic cells $(D C S)\left(1 \times 10^{6}\right)$ treated with sham-HD, or sodium metaperiodate (SMP)-HD $(100 \mu \mathrm{g} / \mathrm{mL}$, 24 hours) were transferred (i.p.) to C57BL/6 mice 48 hours before DNBS challenge (4 mg i.r.). Macroscopy (A) and histology (B) damage scores were analyzed by Kruskal-Wallis test with Dunn posttest to positive control. C: Representative micrographs of hematoxylin and eosin-stained cross sections of colonic tissue. D and E: Levels of Il-4 and Il-10 were measured from supernatants of stimulated splenocytes $\left(5 \times 10^{6}, 2 \mu \mathrm{g} / \mathrm{mL}\right.$ concanavalin A, 48 hours) and analyzed by one-way analysis of variance with Tukey posttest. G-J: Major histocompatibility complex class II knockout (MHC II KO) DCs treated with sham HD, or SMP-HD were transferred to C57BL/6 mice 48 hours before DNBS challenge. Macroscopy (F) and histology (G) damage scores were analyzed by Kruskal-Wallis test with Dunn posttest to positive control. H: Representative micrographs of hematoxylin and eosin-stained cross sections of colonic tissue. I and J: Levels of Il-4 and Il-10 were measured from supernatants of stimulated splenocytes, and analyzed by one-way analysis of variance with Tukey posttest. Data are expressed as means \pm SEM. $n=3$ (A, B, D-G, I, and J, controls); $n=5$ (A, B, D, and E, HD-DCs + DNBS, SMP HD-DCs + DNBS; F, G, I, and J, DNBS, MHC II KO SMP HD-DCs + DNBS); $n=6(\mathbf{A}, \mathbf{B}, \mathbf{D}$, and $\mathbf{E}$, DNBS; F, $\mathbf{G}, \mathbf{I}$, and $\mathbf{J}$, MHC II KO HD-DCs + DNBS), all from one experiment. ${ }^{*} P \leq 0.05$ (D and $\mathbf{E}$, versus all groups; $\mathbf{F}$ and $\left.\mathbf{G}\right) ;{ }^{\dagger} P \leq 0.05$ versus DNBS group (I and $\left.\mathbf{J}\right)$. Scale bars $=300 \mu \mathrm{m}$. b.d., below detection threshold; L, lumen; $M$, muscle. 


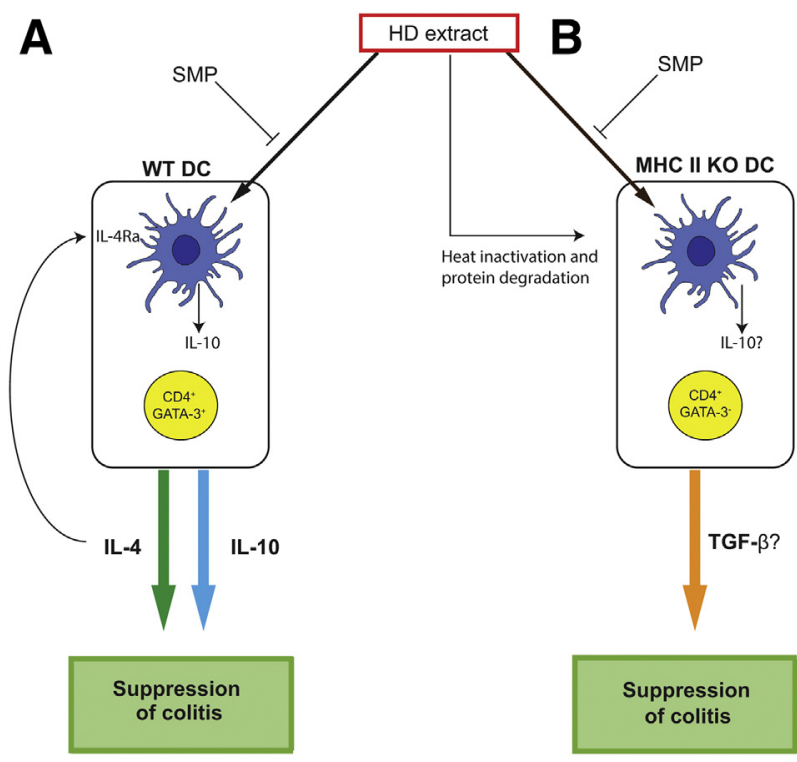

Figure 10 Major histocompatibility complex class II (MHC II)dependent and MHC II-independent suppression of colitis in Hymenolepis diminuta antigen-treated dendritic cells (HD-DCs). A: Adoptive transfer of wild-type (WT) HD-DCs induces GATA-3 expression in $\mathrm{CD}^{+}{ }^{+}$cells, and drives splenic IL-4 and IL-10 in recipients. As previously reported, WT HD-DCs educate an IL-4-producing $\mathrm{CD}^{+}{ }^{+}$cell that can suppress colitis in recipients via IL-10 production. ${ }^{18,19}$ B: In an alternative pathway, HD-DCs that lack MHC II do not up-regulate Gata- $3^{+} \mathrm{Cd} 4^{+}$cells, or drive splenic Il-4 or Il-10 in recipient mice, but inhibit colitis, in part through an anti-colitic $\mathrm{Cd}^{+}$splenocyte. The bioactive molecule(s) in the HD extract involved in educating an immune-regulatory/anti-colitic DC are sodium metaperiodate (SMP) sensitive.

absence of $\mathrm{Cd}^{+}{ }^{+} \mathrm{Gata}-3^{+}$cell induction and limited increases in $\mathrm{Cd} 4^{+} \mathrm{Foxp}^{+}{ }^{+} \mathrm{Helios}^{-}$cells in mice, a finding compatible with the observation that $\mathrm{MHC} \mathrm{II}^{-1-}$ HD-DCs did not affect the outcome of disease in DNBS-treated recombination-activating gene $1^{-1-}$ mice. Thus, in the absence of cognate interaction via MHC II, HD-DCs instruct the development of an anti-colitic $\mathrm{T}$ cell and/or enhance the potency of low-frequency T-regulatory cells, as suggested by Hang et al. ${ }^{60}$ Although surprising, this finding is not unprecedented: Walsh et $\mathrm{al}^{61}$ reported the induction of neuroprotective $\mathrm{Cd} 4^{+} \mathrm{T}$ cells in the central nervous system via an MHC II-independent mechanism. Although MHC II was absent from transferred HD-DCs, MHC II-competent antigen-presenting cells in the recipient mouse could be conditioned within the microenvironment, which may contribute to the observed $\mathrm{Cd} 4^{+}$ T-cell-mediated effect in protection from colitis. Regardless, $\mathrm{MHC} \mathrm{II}^{-/-}$HD-DCs evoke, either directly or indirectly, a pathway of $\mathrm{Cd}^{+} \mathrm{T}$ cell-mediated protection from colitis.

Intriguingly, treatment of the HD extract with sodium metaperiodate, an oxidizing agent that alters glycan conformation by opening saccharide rings, rendered it incapable of evoking the anti-colitic phenotype in WT or MHC $\mathrm{II}^{-l-}$ DCs. Similarly, a sodium metaperiodate-sensitive glycan was implicated in the suppression of macrophage activation by HD-derived antigens. ${ }^{23}$ Although poorly characterized, a variety of bioactive immunoregulatory glycans from helminths can modify DC and other immune-cell activity. ${ }^{30,32,45,62}$ These data indicate that within the mixed molecule milieu of the HD extract, glycans are crucial in the anti-colitic effect that operates via both MHC II-dependent and MHC II-independent pathways.

Helminth extracts have been shown to activate Toll-like receptor $2,{ }^{63}$ raising the potential of $\mathrm{HD}$ extract education of WT or MHC $\mathrm{II}^{-/-}$DCs occurring via these or other germ line-encoded sensors of pathogens and how microbial factors may influence the system. Moreover, the gut microbiota are a determinant of digestive health, ${ }^{64}$ and infection with helminths results in shifts of the composition of the microbiota. It is unknown whether cellular immunotherapy would affect the composition or function of the gut microbiota, and any consequence of an altered microbiota on the inhibition of colitis also is unknown. The interaction of the gut microbiota and enteric helminths is an emerging and intriguing area that will undoubtedly affect digestive health and will have to be considered in the development of helminth therapy, the use of helminthderived molecules in the treatment of disease, and helminth antigen-based cellular immunotherapy. ${ }^{8}$

In summary, in exploring the mechanism of HD-DC suppression of DNBS-colitis in mice, we found that protection from colitis was dependent on a heat- and proteinase $\mathrm{K}$-insensitive, sodium metaperiodate-sensitive glycan(s) in the worm extract and on the expression of Ccr7 on DCs. With MHC II present, HD-DCs mobilized $\mathrm{Cd} 44^{+} \mathrm{Gata}-3^{+} \mathrm{T}$ cells and ameliorated colitis via Il-4 and Il-10 signaling from recipient and donor cells (Figure 10). ${ }^{18,19}$ However, in the absence of MHC II, the mechanism of inhibition of DNBS-induced colitis by HD-DCs is dramatically different: Neither splenic $\mathrm{Cd}^{+}{ }^{+}$ata- $3^{+}$cells nor $\mathrm{Il}-10$ or Il-4 is evoked. Although the signaling mechanism evoked by the transfer of MHC $\mathrm{II}^{-}$HD-DCs is unclear, we suggest that redundancy exists within the immune system such that the absence of MHC II can, to some degree, be compensated. Considering the use of HD-DCs in human colitis, we speculate that the promotion of $\mathrm{Ccr} 7$ expression could enhance the efficacy of this potential novel therapy, which would be effective in patients who, for whatever reason (eg, concomitant viral infection) have a compromised ability to express MHC II.

\section{Acknowledgments}

We thank Dr. Karen Poon (University of Calgary, Calgary, Alberta, Canada) for her assistance with flow cytometry.

D.M.M. is the guarantor of this work, and as such has full access to the data in the study, and takes full responsibility for data integrity, and data analysis. 


\section{Supplemental Data}

Supplemental material for this article can be found at https://doi.org/10.1016/j.ajpath.2018.07.008.

\section{References}

1. Anguille S, Smits EL, Bryant C, Van ACker HH, Goosens H, Lion E, Fromm PD, Hart DN, van Tendeloo AF, Berneman ZN: Dendritic cells as pharmacological tools for cancer immunotherapy. Pharmacol Rev 2015, 67:731-753

2. Garcia F, Climent N, Assoumou L, Gil C, Gonzalez N, Alcami J, Leon A, Romeu J, Dalmau J, Martinez-Picado J, Lifson J, Autran B, Costagliola D, Clotet B, Gatell JM, Plana M, Gallart T: A therapeutic dendritic cell-based vaccine for HIV-1 infection. J Infect Dis 2011, 203:473-478

3. Garcia F, Plana M, Climent N, Leon A, Gatell JM, Gallart T: Dendritic cell based vaccines for HIV infection: the way ahead. Hum Vaccin Immunother 2013, 9:2445-2452

4. Cabezón R, Benítez-Ribas D: Therapeutic potential of tolerogenic dendritic cells in IBD: from animal models to clinical application. Clin Dev Immunol 2013, 2013:789814

5. Pedersen AE, Gad M, Kristensen NN, Haase C, Nielsen CH, Claesson MH: Tolerogenic dendritic cells pulsed with enterobacterial extract suppress development of colitis in the severe combined immunodeficiency transfer model. Immunology 2007, 121:526-532

6. Yamanishi H, Murakami H, Ikeda Y, Abe M, Kumagi T, Hiasa Y, Matsuura B, Onji M: Regulatory dendritic cells pulsed with carbonic anhydrase I protect mice from colitis induced by $\mathrm{CD} 4{ }^{+} \mathrm{CD} 25^{-} \mathrm{T}$ cells. J Immunol 2012, 188:2164-2172

7. de Jesus ER, Isidro RA, Cruz ML, Marty H, Appleyard CB: Adoptive transfer of dendritic cells expressing Fas ligand modulates intestinal inflammation in a model of inflammatory bowel disease. J Clin Cell Immunol 2016, 7

8. Lopes F, Matisz C, Reyes JL, Jijon H, Al-Darmaki A, Kaplan GG, McKay DM: Helminth regulation of immunity: a three-pronged approach to treat colitis. Inflamm Bowel Dis 2016, 10:2499-2512

9. Schölmerich J, Fellermann K, Seibold FW, Rogler G, Langhorst J, Howaldt S, Novacek G, Petersen AM, Bachmann O, Matthes H, Hesselbarth N, Teich N, Wehkamp J, Klaus J, Ott C, Dilger K, Greinwald R, Mueller R; International TRUST-2 Study Group: A randomised, double-blind, placebo-controlled trial of Trichuris suis ova in active Crohn's disease. J Crohns Colitis 2017, 11:390-399

10. Fleming JO, Hernandez G, Hartman L, Maksimovic J, Nace S, Lawler B, Risa T, Cook T, Agni R, Reichelderfer M, Luzzio C, Rolak L, Field A, Fabry Z: Safety and efficacy of helminth treatment in relapsing-remitting multiple sclerosis: results of the HINT 2 clinical trial. Mult Scler 2017. doi:10.1177/1352458517736377, [Epub ahead of print]

11. Croese J, O'Neil J, Masson J, Cooke S, Melrose W, Pritchard D, Speare R: A proof of concept study establishing Necator americanus in Crohn's patients and reservoir donors. Gut 2006, 55:136-137

12. Bager $\mathrm{P}$, Arnved $\mathrm{J}$, Ronborg $\mathrm{S}$, Wohlfahrt J, Poulsen LK, Westergaard T, Petersen HW, Kristensen B, Thamsborg S, Roepstorff A, Kapel C, Melbye M: Trichuris suis ova therapy for allergic rhinitis: a randomized, double-blind, placebo-controlled clinical trial. J Allergy Clin Immunol 2010, 125:123-130.e1

13. Hewitson JP, Grainger JR, Maizels RM: Helminth immunoregulation: the role of parasite secreted proteins in modulating host immunity Mol Biochem Parasitol 2009, 167:1-11

14. Ruyssers NE, De Winter BY, De Man JG, Loukas A, Pearson MS, Weinstock JV, Van den Bossche RM, Martinet W, Pelckmans PA, Moreels TG: Therapeutic potential of helminth soluble proteins in TNBS-induced colitis in mice. Inflamm Bowel Dis 2009, 15 491-500
15. Carranza F, Falcon CR, Nunez N, Knubel C, Correa SG, Bianco I, Maccioni M, Fretes R, Triquell MF, Motran CC, Cervi L: Helminth antigens enable $\mathrm{CpG}$-activated dendritic cells to inhibit the symptoms of collagen-induced arthritis through Foxp $3^{+}$regulatory T cells. PLoS One 2012, 7:e40356

16. Sofronic-Milosavljevic LJ, Radovic I, Ilic N, Majstorovic I, Cvetkovic J, Gruden-Movsesijan A: Application of dendritic cells stimulated with Trichinella spiralis excretory-secretory antigens alleviates experimental autoimmune encephalomyelitis. Med Microbiol Immunol 2013, 202:239-249

17. Falcon C, Carranza F, Martinez FF, Knubel CP, Masih DT, Motran CC, Cervi L: Excretory-secretory products (ESP) from Fasciola hepatica induce tolerogenic properties in myeloid dendritic cells. Vet Immunol Immunopathol 2010, 137:36-46

18. Matisz CE, Leung G, Reyes JL, Wang A, Sharkey KA, McKay DM: Adoptive transfer of helminth antigen-pulsed dendritic cells protects against the development of experimental colitis in mice. Eur J Immunol 2015, 45:3126-3139

19. Matisz CE, Faz-López B, Thomson E, Al Rajabi A, Lopes F, Terrazas LI, Wang A, Sharkey KA, McKay DM: Suppression of colitis by adoptive transfer of helminth antigen-treated dendritic cells requires interleukin-4 receptor-[alpha] signaling. Sci Rep 2017, 7: 40631

20. Stumptner-Cuvelette P, Morchoisne S, Dugast M, Le Call S, Raposo G, Schwartz O, Benaroch P: HIV-1 nef impairs MHC class II antigen presentation and surface expression. Proc Natl Acad Sci U S A 2001, 98:12144-12149

21. Zuo J, Rowe M: Herpes viruses placating the unwilling host: manipulation of the MHC class II antigen presentation pathway. Viruses 2012, 4:1335-1353

22. Kim HM, Lee BR, Lee ES, Kwon MH, Huh JH, Kwon BE, Park EK, Chang SY, Kweon MN, Kim PH, Ko HJ, Chung CH: iNKT cells prevent obesity-induced hepatic steatosis in mice in a $\mathrm{C}-\mathrm{C}$ chemokine receptor 7-dependent manner. Int J Obes (Lond) 2018, 42:270-279

23. Johnston MJ, Wang A, Catarino ME, Ball L, Phan VC, MacDonald JA, McKay DM: Extracts of the rat tapeworm, Hymenolepis diminuta, suppress macrophage activation in vitro and alleviate chemically induced colitis in mice. Infect Immun 2010, 78: $1364-1375$

24. Lutz MB, Kukutsch NA, Ogilvie AL, Robner S, Koch F, Romani N, Schuler G: An advanced culture method for generating large quantities of highly pure dendritic cells from mouse bone marrow. J Immunol Methods 1999, 223:77-92

25. Hunter MM, Wang A, Hirota CL, McKay DM: Neutralizing anti-IL10 antibody blocks the protective effect of tapeworm infection in a murine model of chemically induced arthritis. J Immunol 2005, 174: $7368-7375$

26. Leung G, Petri B, Reyes JL, Wang A, Iannuzzi J, Mckay DM: Cryopreserved IL-4-treated macrophages attenuate murine colitis in an integrin B7-dependent manner. Mol Med 2015, 21:924-936

27. Martin-Fontecha A, Sebastiani S, Höpken UE, Uguccioni M, Lipp M, Lanzavecchia A, Sallusto F: Regulation of dendritic cell migration to the draining lymph node: impact on $\mathrm{T}$ lymphocyte traffic and priming. J Exp Med 2003, 198:615-621

28. Everts B, Hussaarts L, Driessen NN, Meevissen $\mathrm{MH}$ Schramm G, van der Ham AJ, van der Hoeven B, Scholzen T, Burgdorf S, Mohrs M, Pearce EJ, Hokke CH, Haas H, Smits HH, Yazdanbakhsh M: Schistosome-derived omega-1 drives Th2 polarization by suppressing protein synthesis following internalization by the mannose receptor. J Exp Med 2012, 209: 1753-1767. S1

29. Casaravilla C, Pittini A, Ruckerl D, Seoane PI, Jenkins SJ, MacDonald AS, Ferreira AM, Allen JE, Diaz A: Unconventional maturation of dendritic cells induced by particles from the laminated layer of larval Echinococcus granulosus. Infect Immun 2014, 82: $3164-3176$ 
30. van Stijn CM, Meyer S, van den Broek M, Bruijns SC, van Kooyk Y, Geyer R, van Die I: Schistosoma mansoni worm glycolipids induce an inflammatory phenotype in human dendritic cells by cooperation of TLR4 and DC-SIGN. Mol Immunol 2010, 47:1544-1552

31. Harn AD, McDonals J, Atochina O, Da'dara AA: Modulation of host immune responses by helminth glycans. Immunol Rev 2009, 230: 247-257

32. Rodríguez E, Noya V, Cervi L, Chiribao ML, Brossard N, Chiale C, Carmona C, Giacomini C, Freire T: Glycans from Fasciola hepatica modulate the host immune response and TLR-induced maturation of dendritic cells. PLoS Negl Trop Dis 2015, 9:e0004234

33. Tawill S, Le Goff L, Ali F, Blaxter M, Allen JE: Both free-living and parasitic nematodes induce a characteristic TH2 response that is dependent on the presence of intact glycans. Infect Immun 2004, 72: 398-407

34. Wilson MS, Taylor MD, Balic A, Finney CA, Lamb JR, Maizels RM: Suppression of allergic airway inflammation by helminth-induced regulatory T cells. J Exp Med 2005, 202:1199-1212

35. Hunter MM, Wang A, Parhar KS, Johnston MJ, Van Rooijen N, Beck PL, McKay DM: In vitro-derived alternatively activated macrophages reduce colonic inflammation in mice. Gastroenterology 2010, 138:1395-1405

36. Sala E, Genua M, Petti L, Anselmo A, Arena V, Cibella J, Zanotti L, D’Alessio S, Scaldaferri F, Luca G, Arato I, Calafiore R, Sgambato A, Rutella S, Locati M, Danese S, Vetrano S: Mesenchymal stem cells reduce colitis in mice via release of TSG6, independently of their localization to the intestine. Gastroenterology 2015, 149:163-176

37. Creusot RJ, Yaghoubi SS, Chang P, Chia J, Contag CH, Gambhir SS, Fathman CG: Lymphoid-tissue-specific homing of bone-marrowderived dendritic cells. Blood 2009, 113:6638-6647

38. Jenne CN KP: Immune surveillance by the liver. Nat Immunol 2013, 14:996-1006

39. Riol-Blanco L, Sanchez-Sanchez N, Torres A, Tejedor A, Narumiya S, Corbi AL, Sanchez-Mateos P, Rodriguez-Fernandez JL: The chemokine receptor CCR7 activates in dendritic cells two signaling modules that independently regulate chemotaxis and migratory speed. J Immunol 2005, 174:4070-4080

40. Mori S, Nakano H, Aritomi K, Wang C-R, Gunn MD, Kakiuchi T: Mice lacking expression of the chemokines CCL21-ser and CCL19 (plt mice) demonstrate delayed but enhanced $\mathrm{T}$ cell immune responses. J Exp Med 2001, 193:207-218

41. Junt T, Scandella E, Forster R, Krebs P, Krautwald S, Lipp M, Hengartner H, Ludewig B: Impact of CCR7 on priming and distribution of antiviral effector and memory CTL. J Immunol 2004, 173: 6684-6693

42. Ricart BG, John B, Lee D, Hunter CA, Hammer DA: Dendritic cells distinguish individual chemokine signals through CCR7 and CXCR4. J Immunol 2011, 186:53-61

43. Whelan M, Harnett MM, Houston KM, Patel V, Harnett W, Rigley KP: A filarial nematode-secreted product signals dendritic cells to acquire a phenotype that drives development of Th2 cells. J Immunol 2000, 164:6453-6460

44. MacDonald AS, Straw AD, Bauman B, Pearce EJ: CD8- dendritic cell activation status plays an integral role in influencing Th2 response development. J Immunol 2001, 167:1982-1988

45. Thomas PG, Carter MR, Atochina O, Da'Dara AA, Piskorska D, McGuire E, Harn DA: Maturation of dendritic cell 2 phenotype by a helminth glycan uses a toll-like receptor 4-dependent mechanism. J Immunol 2003, 17:5837-5841

46. Balic A, Harcus Y, Holland MJ, Maizels RM: Selective maturation of dendritic cells by Nippostrongylus brasiliensis-secreted proteins drives Th2 immune responses. Eur J Immunol 2004, 34:3047-3059

47. Connor LM, Tang SC, Camberis M, Le Gros G, Ronchese F: Helminth-conditioned dendritic cells prime $\mathrm{CD}^{+}{ }^{+} \mathrm{T}$ cells to IL-4 production in vivo. J Immunol 2014, 193:2709-2717
48. Liu JY, Li LY, Yang XZ, Li J, Zhong G, Wang J, Li LJ, Ji B, Wu ZQ, Liu H, Yang X, Liu PM: Adoptive transfer of dendritic cells isolated from helminth-infected mice enhanced $\mathrm{T}$ regulatory cell responses in airway allergic inflammation. Parasite Immunol 2011, 33:525-534

49. Persaud R, Wang A, Reardon C, McKay DM: Characterization of the immuno-regulatory response to the tapeworm Hymenolepis diminuta in the non-permissive mouse host. Int J Parasitol 2007, $37: 393-403$

50. Robinson MW, Alvarado R, To J, Hutchinson AT, Dowdell SN, Lund M, Turnbull L, Whitchurch CB, O'Brien BA, Dalton JP, Donnelly S: A helminth cathelicidin-like protein suppresses antigen processing and presentation in macrophages via inhibition of lysosomal vatpase. FASEB J 2012, 26:4614-4627

51. Hartmann W, Brenz Y, Tanyi Kingsley M, Ajonina-Ekoti I, Brattig NW, Liebau E, Breloer M: Nematode-derived proteins suppress proliferation and cytokine production of antigen-specific $\mathrm{T}$ cells via induction of cell death. PLoS One 2013, 8:e68380

52. Wang A, McKay DM: Immune modulation by a high molecular weight fraction from the rat tapeworm Hymenolepis diminuta. Parasitology 2005, 130:575-585

53. Ritter M, Gross O, Kays S, Ruland J, Nimmerjahn F, Saijo S, Tschopp J, Layland LE, Prazeres da Costa C: Schistosoma mansoni triggers dectin-2, which activates the nlrp3 inflammasome and alters adaptive immune responses. Proc Natl Acad Sci U S A 2010, 107:20459-20464

54. Holland KT, Harcus Y, Riches PL, Maizels RM: Proteins secreted by the parasitic nematode Nippostrongylus brasiliensis act as adjuvants for TH2 responses. Eur J Immunol 2000, 30:1977-1987

55. Hamandy ZZ, Scott N, Farrar MD, Wadhwa M, Dilger P, Whitehead TR, Thorpe R, Holland KT, Lodge JP, Carding SR: Treatment of colitis with a comensal gut bacterium engineered to secrete human TGF- $\beta 1$ under the control of dietary xylan 1. Inflamm Bowel Dis 2011, 17:1925-1935

56. Duchman R, Zeitz M: T regulatory cell suppression of colitis: the role of TGF- $\beta$. Gut 2006, 55:604-606

57. Jin Y, Wi HJ, Choi MH, Hong ST, Bae YM: Regulation of antiinflammatory cytokines IL-10 and TGF- $\beta$ in mouse dendritic cells through treatment with Clonorchis sinensis crude antigen. Exp Mol Med 2014, 46:e74

58. Grainger JR, Smith KA, Hewitson JP, McSorley HJ, Harcus Y, Filbey KJ, Finney CA, Greenwood EJ, Knox DP, Wilson MS, Belkaid Y, Rudensky AY, Maizels RM: Helminth secretions induce de novo T cell Foxp3 expression and regulatory function through the TGF-beta pathway. J Exp Med 2010, 207:2331-2341

59. Thronton AM, Korty PE, Tran DQ, Wohlfert EA, Murray PE, Belkaid Y, Shevach EM: Expression of helios, an ikaros transcription factor family member, differentiates thymic-derived from peripherally induced Foxp $3^{+}$T regulatory cells. J Immunol 2010, 184:3433-3441

60. Hang L, Blum AM, Setiawan T, Urban JPJ, Stoyanoff KM, Weinstock JV: Heligmosomoides polygyrus bakeri infection activates colonic Foxp $3^{+} \mathrm{T}$ cells enhancing their capacity to prevent colitis. J Immunol 2013, 191:1927-1934

61. Walsh JT, Hendrix S, Boato F, Smirnov I, Zheng J, Lukens JR, Gadani S, Hechler D, Gölz G, Rosenberger K, Kammertöns T, Vogt J, Vogelaar C, Siffrin V, Radjavi A, Fernandez-Castaneda A, Gaultier A, Gold R, Kanneganti TD, Nitsch R, Zipp F, Kipnis J: MHCII-independent CD4 ${ }^{+} \mathrm{T}$ cells protect injured CNS neurons via IL-4. J Clin Invest 2015, 125:699-714

62. Goodridge HS, Marshall FA, Else KJ, Houston KM, Egan C, AlRiyami L, Liew FY, Harnett W, Harnett MM: Immunomodulation via novel use of TLR4 by the filarial nematode phosphorylcholinecontaining secreted product, ES-62. J Immunol 2005, 174:284-293

63. Correale J, Farez M: Does helminth activation of toll-like receptors modulate immune response in multiple sclerosis patients? Front Cell Infect Microbiol 2012, 2:112

64. Flint HJ, Scott KP, Louis P, Duncan SH: The role of the gut microbiota in nutrition and health. Nat Rev Gastroenterol Hepatol 2012, 9:577-589 